\title{
Kluby jeździeckie - oferta elitarna czy dostępna dla wszystkich?
}

\section{Anna Pawlikowska-Piechotka, Natalia Łukasik}

\section{STRESZCZENIE}

Tematem artykułu jest rozważenie uwarunkowań rozwoju jeździectwa w aglomeracji warszawskiej. Omówiono w nim uwarunkowania rozwoju, potencjały i najistotniejsze bariery, a także możliwości znoszenia ograniczeń oraz działania na rzecz upowszechnienia sportu i rekreacji jeździeckiej. Jest to jeden z wątków tematycznych badań przeprowadzonych w wybranych ośrodkach jeździeckich w aglomeracji warszawskiej, w ramach dwóch kolejnych statutowych projektów badawczych, finansowanych grantem Ministerstwa Nauki i Szkolnictwa Wyższego ds-114 oraz ds-144. Na podstawie zgromadzonego materiału została przygotowana i obroniona na Akademii Wychowania Fizycznego Józefa Piłsudskiego w Warszawie rozprawa doktorska dr Natalii Łukasik Społeczne i kulturowe uwarunkowania rozwoju jeździectwa w Warszawie i gminach sasiednich (promotor: prof. dr hab. inż. arch. Anna PawlikowskaPiechotka). Niniejszy artykuł prezentuje zarys założeń badań, uzyskane rezultaty na podstawie analizy uporządkowanego materiału badań oraz wysunięte syntetyczne wnioski końcowe.

Słowa kluczowe: ośrodki jazdy konnej, jeździectwo, aglomeracja warszawska

\section{Wprowadzenie}

Jeździectwo jest powszechnie uznawane za szczególnie atrakcyjną formą spędzania czasu wolnego, gdyż łączy aktywność fizyczna z bezpośrednim kontaktem ze światem przyrody, wymaga dobrej współpracy ze zwierzęciem. Innym, istotnym walorem uprawiania jazdy konnej jest szczególny wymiar społeczny i emocjonalny tej formy rekreacji. Jeździec musi liczyć się z reakcjami konia, zdobyć jego zaufanie, komunikować i opiekować się nim, inaczej uprawianie jeździectwa nie jest możliwe [Adelman, Knijnik 2013; Luxmoore 2008]. Z kolei uczestnictwo w zajęciach klubowych, wspólne ćwiczenia, jazdy w terenie, udział w turystycznych rajdach konnych - pomagają zacieśnić i wzbogacić więzy w grupie studenckiej, rodziny, znajomych - osób wspólnie uprawiających jazdę konną. Ponadto, dla młodzieży szczególnie atrakcyjne sa zajęcia klubowe związane z kultywowaniem polskiej tradycji rycerskiej i ułańskiej, co wzmacnia kształtowanie postaw patriotycznych i zainteresowanie historia [Geld-Pieprzyca 2005]. Należy też zwrócić uwagę na tak istotny aspekt zdrowotny, jakim jest walor terapeutyczny jazdy konnej. Znane jest i dobrze udokumentowane naukowo dobroczynne działanie hipoterapii w walce z szeregiem niedomagań i ograniczeń, szczególnie w psychicznym i fizycznym upośledzeniu rozwoju dzieci [DiGiacomo 2012; Domżał, Należyty, Solecka 2014; Halemba, Harmaciński 2009; Heipertz-Hengst 1997; Straus 1996, 2013; Strumińska 2003; ZGPTH 
2009, Massini 2010; SJON 2014]. Ważnym walorem jest szeroki uniwersalizm tej formy sportu i rekreacji - do uprawiania jeździectwa nie sa przeszkodą wiek, kondycja fizyczna, niskie umiejętności czy kaprysy pogody, ponieważ poza jazdami w terenie i treningiem sportowym możliwe są stosunkowo łatwe i bezpieczne ćwiczenia na terenie ograniczonym lub w budynku ujeżdżalni [Bruch 2012; Grobelny 1995; McGreevy 2011; Wolframm 2014].

Jesteśmy coraz bardziej świadomi, że warunki życia we współczesnym środowisku wielkich miast i ich sasiedztwie pogarszają się gwałtownie. Ma to odniesienie także do aglomeracji warszawskiej, w której niekorzystne zmiany cywilizacyjne są coraz bardziej odczuwalne [GUS 2007, 2014, 2015, 2016, 2020]. Mieszkańcy są nie tylko narażeni na znaczne zanieczyszczenie powietrza atmosferycznego, wód i gleby, uciążliwy hałas, niekorzystne dla zdrowia zmiany mikroklimatu, ale także na stres i schorzenia związane z malejąca aktywnością ruchową. Jednym ze znanych efektywnych sposobów walki z negatywnymi skutkami urbanizacji jest aktywny i systematyczny wypoczynek codzienny na terenie otwartym, a jedna z jego form może być jazda konna.

W ostatnich dwóch dekadach w Warszawie i jej sassiedztwie (w promieniu $40 \mathrm{~km}$ od Centrum) powstało kilkadziesiąt zarejestrowanych w Polskim Związku Jeździeckim (PZJ) certyfikowanych ośrodków jazdy konnej. Nikt nie prowadzi dokładnych statystyk na temat gospodarstw agroturystycznych, hoteli i pensjonatów oferujących jazdę konną bez certyfikatu PZJ, ale na postawie np. reklam internetowych witryn turystycznych [nocowanie.pl 2020; idara.pl 2020; oferteo.pl 2020; gromada.pl 2020], wiadomo, że istnieje taka oferta. Jest to tendencja obserwowana w całym kraju po 1990 r., kiedy na fali głębokich zmian społeczno-ekonomicznych, jazda konna sportowa i rekreacyjna stały się, w porównaniu z minionym okresem, bardziej w Polsce popularne. Gospodarka rynkowa z jednej strony wykreowała grupę osób o dosyć wysokich dochodach, przede wszystkim klasę średnia, z drugiej umożliwia spełnienie marzeń i ambicji tej grupy o stylu życia osób zamożnych - w tym gry w tenisa, golfa, polo oraz uprawiania jazdy konnej. Popyt jest na tyle duży, że w ciagu ostatniego ćwierćwiecza powstały w naszym kraju liczne ośrodki jazdy konnej o zróżnicowanej ofercie. Tym zmianom towarzyszą organizacje kursów, szkoleń, konkursów i zawodów, rośnie też kadra instruktorska i trenerska, powstają ośrodki, w których można uprawiać jeździectwo rekreacyjne i sportowe, zdobywać odznaki [PZJ 2015, 2020] (ryc. 1, 2).

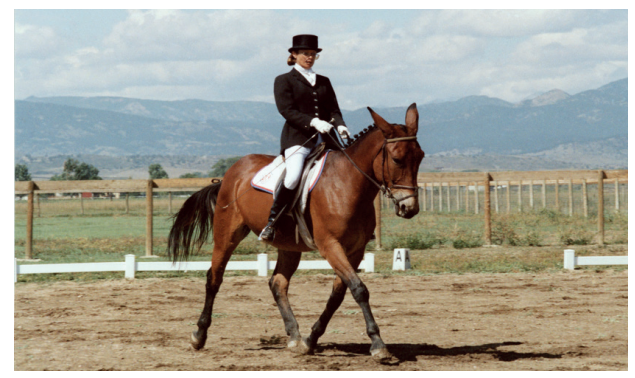

Ryc. 1. Jeździectwo

Rekreacyjne, sportowe oraz wędrówki konne stają się coraz bardziej popularne w naszym społeczeństwie Źródło: Domena Publiczna

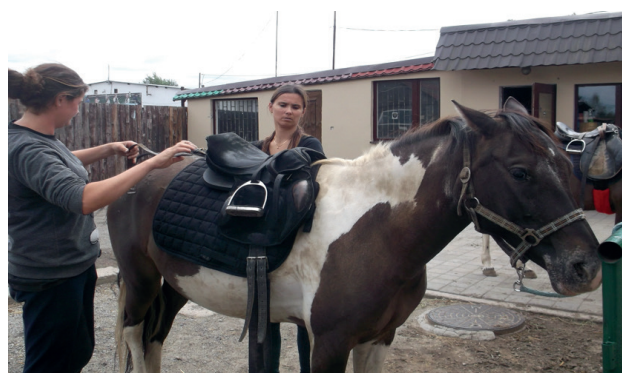

Ryc. 2. Klub jeździecki Dworek w Okuniewie pod Warszawą

Kameralny klub, którego oferta jest ukierunkowana na dzieci, dorosłych, seniorów oraz osoby wymagające hipoterapii 
Sport jeździecki w Polsce, po latach przerw i zaniedbań, wymaga wciąż czasu, cierpliwości i zaangażowania oraz bardzo wysokich nakładów finansowych na odbudowanie liczaccej się na arenie międzynarodowej kadry wyszkolonych koni i sportowców. Pomimo wielu starań, wysokich ambicji i silnego zaangażowania - nie odzyskaliśmy dotąd pozycji, jaką miało polskie jeździectwo sportowe przed II wojną światowa [Chmiel 2009]. Pomimo stale rosnącego zainteresowania jazdą konną w Polsce, ten sport i ta forma rekreacji jest u nas wciąż 10-krotnie mniej popularna niż np. w Wielkiej Brytanii [Mogiła-Lisowska 2010; Torkildsen 2005; Vael 2011].

Celem podjętych badań statutowych na Akademii Wychowania Fizycznego Józefa Piłsudskiego w Warszawie (ds-114 oraz ds-144), była chęć rozeznania uwarunkowań uprawiania sportu i rekreacji przez mieszkańców Warszawy na terenach otwartych, w tym jazdy konnej, poznania najistotniejszych barier oraz zastanowienia się nad możliwościami ich znoszenia. Badania ukierunkowane na kluby jeździeckie, przeprowadzono w wybranych ośrodkach aglomeracji warszawskiej. Niniejszy artykuł prezentuje zarys założeń prac badawczych, wyniki oraz uogólnione konkluzje.

\section{Założenia badań}

\section{Pytania badawcze}

Prace badawcze miały na celu rozeznanie, na przykładzie aglomeracji warszawskiej, oferty klubów jeździeckich, ich dostępność i położenie, program funkcjonalny i infrastrukturę, charakterystykę i oczekiwania ich członków; a na tej podstawie wyróżnienie czynników społeczno-kulturowych wpływających na możliwości uprawiania jeździectwa oraz rozważanie, w jaki sposób można wzmacniać czynniki pozytywne i jak znosić lub niwelować czynniki negatywne.

\section{Materiał i metoda badań}

Badaniami objęto 20 ośrodków jeździeckich położonych na terenie aglomeracji warszawskiej. We wszystkich wybranych do badań klubach zastosowano te same procedury badawcze, techniki i narzędzia: strukturalizowane wywiady z administracją (właścicielami) oraz z członkami klubów, które były prowadzone za pomocą ujednoliconych kwestionariuszy (odpowiednio wzory A i B), w ujednoliconych warunkach, metodą in situ, face to face. Zakres i treść pytań miały na celu zebranie danych opisowych, jakościowych i ilościowych, takich jak zbadanie historii, tradycji i charakterystyki klubu, oferty klubowej i kwalifikacji zaangażowanej tam kadry, sylwetek klubowiczów, motywów czynnego zainteresowania sportem i rekreacją jeździecka, a także identyfikacji utrudnień dotyczących realizacji tych pasji. Ponadto zastosowano technikę zarówno obserwacji jawnej, nieuczestniczącej, jak i jawnej uczestniczącej, strukturalizowane notatki (kwestionariusz C, karta obserwacji klubu), uzupełnione 
dokumentacją fotograficzna. Technika jawna uczestnicząca dotyczyła klubu KJ PGR Bródno w Warszawie, w którym jedna z autorek była zatrudniona przez kilka lat jako instruktor oraz klubu KJ Patataj Kanie, w którym jedna z autorek była przez kilka lat członkiem. We wszystkich pozostałych zastosowano technikę obserwacji jawnej, nieuczestniczącej.

Badania terenowe były realizowane $\mathrm{w}$ trzech etapach: badania właściwe (w latach 2010-2016) w 20 klubach, które zostały poprzedzone badaniami pilotażowymi (2008-2010) w 3 obiektach warszawskich, a po zakończeniu badań właściwych, w celu weryfikacji i aktualizacji danych, odwiedzono ponownie kluby jeździeckie, sprawdzając ich stan za pomocą kwestionariusza wzór 'C' (Karty Ośrodka Jeździeckiego). Scenariusz i założenia badań były zgodne z zaleceniami teoretyków dotyczacymi metod przyjmowanych w tym obszarze problemowym [Cohen, Manion, Morrison 2007; Finn, Elliott-White, Walton 2000; Goodson, Philimore 2004; King 2009; Pilch 2001, Siwiński 1989; Vael 2011, Yan, McCullagh 2004].

W celu uzyskania ujednoliconych cech badanej grupy, zastosowano następujące kryteria selekcji klubów jeździeckich i wyboru do badań:

a) ośrodki jeździeckie znajdujące się w Warszawie i w gminach sąsiednich,

b) ośrodki jeździeckie mające licencję (certyfikat) Polskiego Związku Jeździeckiego,

c) ośrodki jeździeckie mające ofertę jazd zarówno rekreacyjnych, jak i sportowych,

d) ośrodki jeździeckie położone w odległości od centrum Warszawy nie przekraczającej

40 km, co oznacza izochronę dojazdu do PKiN nie większą niż 40 minut samochodem osobowym lub 120 minut komunikacja publiczną.

Wybór ośrodków jeździeckich, spośród położonych w aglomeracji warszawskiej, był podyktowany nie tylko pragmatyzmem ze względu na ułatwienia realizacji badań, lecz także bliskością stałego miejsca zamieszkania, niskiego kosztu dojazdu oraz znajomości opisywanego terenu. O wyborze klubu zaważyły również - wyróżniająca się aktywność, ambicje i zaangażowanie zarządzających ośrodkami jeździeckimi, widoczne w propagowaniu sportu jeździeckiego, np. organizacji kolejnych edycji Regionalnych Zawodów Jeździeckich¹. Wybrane do badań ośrodki miały też ofertę przygotowana pod katem potrzeb osób o różnym stopniu niepełnosprawności, np. parajeździectwo, hipoterapia.

\section{Wyniki badań}

\section{Położenie i wielkość ośrodków jeździeckich}

Wśród wybranych do badań ośrodków jazdy konnej 7 klubów znajdowało się w granicach administracyjnych Warszawy, a 13 na terenie gmin otaczających stolicę. Odległość klubów jeździeckich od centrum miasta, stałym punktem odniesienia był PKiN, nie przekraczała $40 \mathrm{~km}$. Dojazd do nich nie zajmował więcej niż 40 minut jazdy samochodem osobowym lub

\footnotetext{
${ }^{1}$ Należy podkreślić, że naczelną przesłanką tych imprez jest aktywny wypoczynek, zabawa i rywalizacja sportowa wszystkich członków rodziny, uczestnictwo różnych grup wiekowych.
} 
120 minut transportem publicznym. Najbliżej centrum Warszawy, w promieniu do $10 \mathrm{~km}$, położone były: Klub Cavallo Warszawa, Klub Pociecha Warszawa, KJ PGR Bródno, TWKS Służewiec, TKKF Hubert oraz Stajnia Agmaja. Dojazd do nich środkami komunikacji publicznej z centrum nie przekraczał 33 minut, a dojazd samochodem osobowym - 18 minut. Najdalej położone ośrodki od Warszawy (powyżej 30 km): Eko-Farm Milanówek oraz KJ Kuclandia, wymagały dojazdu samochodem osobowym odpowiednio 32 i 40 minut, a transportem publicznym 43 i 85 minut. Te dane obrazuja, że nie zawsze odległość drogowa i izochrona dojazdu zmieniaja się liniowo. Powyżej 60 minut trzeba było poświęcić na dojazd transportem publicznym do większości ośrodków jazdy konnej poza Warszawą. Najczęściej konieczny był tam dojazd z przesiadkami i korzystanie z kolejki podmiejskiej oraz lokalnego autobusu; nierzadko z przystanku komunikacji publicznej - jeszcze dojazd rowerem lub dojście pieszo ${ }^{2}$.

Zajmowany obszar (powierzchnia) badanych klubów jeździeckich wynosił od nieco ponad jednego hektara (SKJ „Trawers” Wolica - 1,3 ha) do kilkudziesięciu hektarów (KJ Stajnia Chojnów Baniocha - ponad 60 ha) $)^{3}$. Ośrodki pozawarszawskie zajmowały zazwyczaj obszar od kilku do kilkunastu hektarów, a kluby jeździeckie położone w Warszawie miały znacznie skromniejsze działki, najczęściej około jednego hektara. Wyjątkiem był Klub Jeździecki Legia Kozielska w Warszawie, zajmujacy rozległy teren o powierzchni aż 8 ha.

\section{Charakterystyka ośrodków}

Mierząc wielkość badanych ośrodków liczbą koni, największym był klub jeździecki Aromer w Józefinie k. Zakrętu (174 konie i kuce), a najmniejszym Klub Cavallo w Łazienkach Królewskich (12 koni i kuców). W badanych ośrodkach przeważały stajnie z 30-70 boksami dla koni - własnych i przyjmowanych do hotelu. Należy dodać, że pod uwagę brano liczbę zwierząt łącznie, pensjonatowych i klubowych, m.in. dlatego, że konie z pensjonatu często biora udział w zajęciach klubowych. W większości klubów odnotowano przewagę liczby koni pensjonatowych nad końmi klubowymi, co świadczyło o rosnącym zainteresowaniu tą ofertą. Należy podkreślić, że poza kilkoma wyjątkami (ośrodek Pepeland w Łomiankach, Stajnia Pociecha w Parku Skaryszewskim, TWKS oraz KJ Aldragho w Piasecznie) wszystkie badane kluby oferowały pensjonat dla koni. Klub jeździecki KJ Aromer w Józefinie k. Piaseczna oferował także ambulatorium i opiekę weterynaryjną.

Na program funkcjonalny i infrastrukturę badanych ośrodków składały się podobne urządzenia terenowe: teren treningowy, czworoboki konkursowe, padoki, krosy, karuzele, parkingi dla gości, placyki zabaw dla dzieci i teren wypoczynku dla dorosłych, parking oraz kubaturowe: kryte hale ujeżdżalni, kryte karuzele, kryte lonżowniki, stajnie, budynki klubo-

\footnotetext{
${ }^{2}$ Dane izochrony dojazdu i odległości drogowej na podstawie aplikacji programu Google Maps (lipiec - wrzesień 2015).

${ }^{3}$ Nie dla wszystkich badanych ośrodków udało się zdobyć takie dane. Nie są znane np. dla klubów: KJ Cavallo w Łazienkach Królewskich w Warszawie (ten ośrodek w 2020 r., już nieistniejący), KJ Pociecha w Parku Skaryszewskim, KJ Stajnia Agmaja Warszawa.
} 
we i gospodarcze. Bezpośrednio przy stajniach znajdowały się pomieszczenia do czyszczenia, składy paszy, siodlarnie i magazyny. Pod względem infrastruktury badane ośrodki jazdy konnej maja dosyć podobny program urządzeń terenowych i zabudowań. We wszystkich badanych ośrodkach cały teren był ogrodzony i oświetlony po zmroku, w tym place treningowe, padoki oraz parking dla gości. Większe kluby, z ambicjami organizacji zawodów sportowych, miały dodatkowo czworoboki konkursowe i krosy, czasami wydzielony plac do treningu skoków, wygrodzone pasy do ćwiczenia galopu oraz trybuny dla widzów. Nawet niewielkie kluby jeździeckie, jak Klub Cavallo w Warszawie, miały kryte ujeżdżalnie umożliwiające naukę jazdy konnej przez cały rok, w każdych warunkach pogodowych. Na tle innych badanych ośrodków jazdy konnej, KJ Pepeland w Łomiankach miał niezwykle silnie rozbudowany segment dodatkowych urządzeń sportowo-rekreacyjnych: korty tenisowe, halę do gier sportowych, park trampolin, placyk zabaw dla dzieci o bogatym programie, park linowy, mini zoo, miejsce do grilla. Jeden z klubów miał w ofercie kryta pływalnię i SPA (KJ Szumawa), inny - poza klubowym barkiem, także restaurację (KJ Baniocha). Z przeprowadzonych wywiadów wynikało, że w trosce o wzbogacanie oferty klubów jeździeckich właściciele starali się coraz energiczniej o urozmaicenie nie tylko infrastruktury bezpośrednio związanej z jeździectwem, ale i uzupełniajacej, jakimi sa atrakcyjnie urządzone tereny wypoczynku i zajęć sportowych dzieci i dorosłych. Właściciele pozamiejskich ośrodków, dysponując odpowiednimi rezerwami terenowymi dla nowych inwestycji, zamierzali budować place treningowe, padoki, karuzele, kryte ujeżdżalnie. W wielu klubach, z uwagi na organizację częstych imprez klubowych (zawodów sportowych, wspólnych spotkań towarzyskich) ważnym elementem zespołu był budynek klubowy, z salą kominkowa, kawiarnia, restauracja, sanitariatami i szatniami, pomieszczeniami administracji, technicznymi, sklepem z akcesoriami jeździeckimi. Ośrodki jeździeckie oferowały także miejsca noclegowe, dysponując od kilku do kilkunastu pokojami gościnnymi. Przy domu klubowym, w zadbanym ogródku, bardzo często był założony plac zabaw dla dzieci, stały parasole i meble wypoczynkowe. Ponadto, przy kilku ośrodkach jazdy konnej istniały wysokiej kategorii restauracje z ambicjami wyszukanej oferty kulinarnej, nastawione już nie tylko na obsługę gości klubowych, ale również osoby przyjeżdżające specjalnie do restauracji (przykładem jest restauracja w ośrodku jeździeckim Stajnia Chojnów Baniocha pod Warszawa) (tabele 1, 2; ryc. 3, 4).

Tabela 1. Położenie, wielkość, oferta, program funkcjonalny i infrastruktura ośrodków jeździeckich

\begin{tabular}{|l|c|c|c|l|}
\hline \multicolumn{1}{|c|}{$\begin{array}{c}\text { Nazwa klubu } \\
\text { i lokalizacja }\end{array}$} & $\begin{array}{c}\text { Jazda } \\
\text { rekreacyjna }\end{array}$ & $\begin{array}{c}\text { Jazda } \\
\text { sportowa }\end{array}$ & $\begin{array}{c}\text { Liczba } \\
\text { koni }\end{array}$ & $\begin{array}{c}\text { Program funkcjonalny } \\
\text { i infrastruktura klubu }\end{array}$ \\
\hline $\begin{array}{l}\text { Klub Cavallo } \\
\text { Łazienki Królewskie } \\
\text { (BP, WD) }\end{array}$ & + & - & 12 & $\begin{array}{l}\text { Stajnie, ujeżdżalnia kryta, teren } \\
\text { treningowy, padoki }\end{array}$ \\
\hline $\begin{array}{l}\text { Klub Pociecha } \\
\text { Park Skaryszewski } \\
\text { (BP, WD) }\end{array}$ & + & - & 10 & $\begin{array}{l}\text { Stajnie, budynek } \\
\text { administracyjno-gospodarczy, } \\
\text { padoki }\end{array}$ \\
\hline
\end{tabular}




\begin{tabular}{|c|c|c|c|c|}
\hline $\begin{array}{l}\text { Nazwa klubu } \\
\text { i lokalizacja }\end{array}$ & $\begin{array}{c}\text { Jazda } \\
\text { rekreacyjna }\end{array}$ & $\begin{array}{c}\text { Jazda } \\
\text { sportowa }\end{array}$ & $\begin{array}{l}\text { Liczba } \\
\text { koni }\end{array}$ & $\begin{array}{l}\text { Program funkcjonalny } \\
\text { i infrastruktura klubu }\end{array}$ \\
\hline $\begin{array}{l}\text { Klub Jeździecki } \\
\text { TWKS Tory } \\
\text { Służewieckie (BP, } \\
\text { WD) }\end{array}$ & + & + & 120 & $\begin{array}{l}\text { Stajnie, tor treningowy, } \\
\text { tor wyścigowy, budynki } \\
\text { gospodarcze, padoki, parking } \\
\text { dla gości klubu }\end{array}$ \\
\hline $\begin{array}{l}\text { Klub Jeździecki } \\
\text { Aldragho, Józefosław, } \\
\text { Piaseczno (BW, WD) }\end{array}$ & + & + & 14 & $\begin{array}{l}\text { Stajnie, padok, ujeżdżalnia } \\
\text { kryta (tymczasowa), budynki } \\
\text { administracji i gospodarcze, } \\
\text { dom klubowy, parking dla } \\
\text { gości, tereny wypoczynku dla } \\
\text { dzieci i dorosłych }\end{array}$ \\
\hline $\begin{array}{l}\text { Klub jeździecki } \\
\text { Aromer, Józefin k. } \\
\text { Zakrętu } \\
\text { (BW, WD) }\end{array}$ & + & + & 174 & $\begin{array}{l}\text { Stajnie, teren treningowy, } \\
\text { ujeżdżalnia kryta, karuzela } \\
\text { dla koni, padoki, czworobok } \\
\text { konkursowy, dom klubowy, } \\
\text { parking dla gości, teren } \\
\text { wypoczynku dla dzieci } \\
\text { i dorosłych }\end{array}$ \\
\hline $\begin{array}{l}\text { Filmowa Stajnia } \\
\text { Treningowa Bałaguła } \\
\text { Dąbrowa Leśna } \\
\text { k. Łomianek (BW, } \\
\text { WD) }\end{array}$ & + & + & 22 & $\begin{array}{l}\text { Stajnie, padok, lonżownik, } \\
\text { ujeżdżalnia, dom klubowy, } \\
\text { parking dla gości, miejsce } \\
\text { wypoczynku dla dzieci } \\
\text { i dorosłych }\end{array}$ \\
\hline $\begin{array}{l}\text { Ośrodek Jeździecki } \\
\text { PGR Bródno Sp. } \\
\text { z o.o. Warszawa } \\
\text { (BW, WD) }\end{array}$ & + & + & 64 & $\begin{array}{l}\text { Stajnie, padoki, } 3 \text { ujeżdżalnie, } \\
\text { hala ujeżdżalni krytej, kryty } \\
\text { lonżownik, kros, budynek } \\
\text { klubowy, parking dla gości } \\
\text { teren wypoczynku dla dzieci } \\
\text { i dorosłych }\end{array}$ \\
\hline $\begin{array}{l}\text { Klub jeździecki } \\
\text { Dworek } \\
\text { w Okuniewie } \\
\text { k. Warszawy } \\
\text { (BW, WD) }\end{array}$ & + & + & 36 & $\begin{array}{l}\text { Stajnie, padoki, plac } \\
\text { treningowy oświetlony, teren } \\
\text { do skoków ogrodzony, kryta } \\
\text { ujeżdżalnia, dom klubowy, } \\
\text { parking dla gości, miejsce } \\
\text { wypoczynku dla dzieci } \\
\text { i dorosłych }\end{array}$ \\
\hline
\end{tabular}




\begin{tabular}{|c|c|c|c|c|}
\hline $\begin{array}{l}\text { Nazwa klubu } \\
\text { i lokalizacja }\end{array}$ & $\begin{array}{c}\text { Jazda } \\
\text { rekreacyjna }\end{array}$ & $\begin{array}{c}\text { Jazda } \\
\text { sportowa }\end{array}$ & $\begin{array}{l}\text { Liczba } \\
\text { koni }\end{array}$ & $\begin{array}{l}\text { Program funkcjonalny } \\
\text { i infrastruktura klubu }\end{array}$ \\
\hline $\begin{array}{l}\text { Ośrodek Jeździecki } \\
\text { Eko-Farm } \\
\text { (BW, WD) }\end{array}$ & + & + & 35 & $\begin{array}{l}\text { Stajnie, teren treningowy, } \\
\text { padoki, hala ujeżdżalni krytej, } \\
\text { dom klubowy, parking dla } \\
\text { gości, miejsce wypoczynku dla } \\
\text { dzieci i dorosłych }\end{array}$ \\
\hline $\begin{array}{l}\text { Ognisko TKKF } \\
\text { Hubert Warszawa } \\
\text { (BW, WD) }\end{array}$ & + & + & 39 & $\begin{array}{l}\text { Stajnie, teren treningu, } \\
\text { ujeżdżalnia kryta, padoki, dom } \\
\text { klubowy, parking dla gości, } \\
\text { miejsce wypoczynku }\end{array}$ \\
\hline $\begin{array}{l}\text { Klub Jeździecki Legia } \\
\text { Kozielska, Warszawa } \\
\text { (BW, WD) }\end{array}$ & + & + & 110 & $\begin{array}{l}\text { Stajnie, padoki, czworobok } \\
\text { konkursowy, kros, } \\
\text { hipodrom trawiasty, } 2 \text { place } \\
\text { treningowe, ujeżdżalnia } \\
\text { kryta, budynki administracji } \\
\text { i gospodarcze, parking dla } \\
\text { gości, pomieszczenia klubowe } \\
\text { (sanitariaty, szatnie) }\end{array}$ \\
\hline $\begin{array}{l}\text { Kuclandia - LKJ. } \\
\text { Klub jeździecki, } \\
\text { Książenice k. } \\
\text { Warszawy (BW, WD) }\end{array}$ & + & + & 30 & $\begin{array}{l}\text { Stajnie, } 2 \text { ujeżdżalnie, dwa } \\
\text { czworoboki konkursowe, } \\
\text { ujeżdżalnia kryta, padoki, } \\
\text { dom klubowy, budynki } \\
\text { gospodarcze, parking dla gości, } \\
\text { miejsce wypoczynku dla dzieci } \\
\text { i dorosłych }\end{array}$ \\
\hline $\begin{array}{l}\text { Uczniowski Klub } \\
\text { Sportowy Szkoła } \\
\text { Jazdy Konnej } \\
\text { PATATAJ Kanie k. } \\
\text { Pruszkowa (BW, WD) }\end{array}$ & + & + & 145 & $\begin{array}{l}\text { Stajnie, padoki, } 5 \text { ujeżdżalni } \\
\text { (jedna z nich zimą jest } \\
\text { przekrywana powłoką } \\
\text { balonowa), kros, budynki } \\
\text { gospodarcze, budynek } \\
\text { klubowy, miejsce wypoczynku } \\
\text { dla dzieci i dorosłych, parking } \\
\text { dla gości }\end{array}$ \\
\hline
\end{tabular}




\begin{tabular}{|c|c|c|c|c|}
\hline $\begin{array}{l}\text { Nazwa klubu } \\
\text { i lokalizacja }\end{array}$ & $\begin{array}{c}\text { Jazda } \\
\text { rekreacyjna }\end{array}$ & $\begin{array}{c}\text { Jazda } \\
\text { sportowa }\end{array}$ & $\begin{array}{l}\text { Liczba } \\
\text { koni }\end{array}$ & $\begin{array}{l}\text { Program funkcjonalny } \\
\text { i infrastruktura klubu }\end{array}$ \\
\hline $\begin{array}{l}\text { Ośrodek jeździecki } \\
\text { Pepeland Dziekanów } \\
\text { Nowy k. Łomianek } \\
\text { (BW, WD) }\end{array}$ & + & + & 28 & $\begin{array}{l}\text { Stajnie, padoki, ujeżdżalnia, } \\
\text { ujeżdżalnia kryta, hala } \\
\text { sportowa, budynki } \\
\text { gospodarcze, budynek } \\
\text { klubowy, teren zabaw dla } \\
\text { dzieci i gier sportowych dla } \\
\text { dorosłych, korty tenisowe, } \\
\text { park trampolin, park linowy, } \\
\text { mini zoo, parking dla gości }\end{array}$ \\
\hline $\begin{array}{l}\text { TKKF Ognisko } \\
\text { Podkowa, Podkowa } \\
\text { Leśna k. Warszawy } \\
\text { (BW, WD) }\end{array}$ & + & + & 38 & $\begin{array}{l}\text { Stajnie, } 2 \text { ujeżdżalnie, } \\
\text { czworobok konkursowy, } \\
\text { padoki, hala ujeżdżalni krytej, } \\
\text { budynek klubowy, parking dla } \\
\text { gości }\end{array}$ \\
\hline $\begin{array}{l}\text { Stajnia Agmaja, } \\
\text { Warszawa (BW, WD) }\end{array}$ & + & + & 25 & $\begin{array}{l}\text { Stajnie, padoki, ujeżdżalnia, } \\
\text { kros, ujeżdżalnia kryta, } \\
\text { budynek gospodarczy, parking } \\
\text { dla gości }\end{array}$ \\
\hline $\begin{array}{l}\text { Stajnia Chojnów, } \\
\text { Baniocha } \\
\text { k. Warszawy (BW, } \\
\text { WD) }\end{array}$ & + & + & 75 & $\begin{array}{l}\text { Stajnie, padoki, } 2 \text { ujeżdżalnie, } \\
\text { ujeżdżalnie pod namiotem } \\
\text { i hala ujeżdżalni krytej, } \\
\text { budynki gospodarcze, budynek } \\
\text { klubowy z restauracja, parking } \\
\text { dla gości, rozległe tereny } \\
\text { rekreacyjno-wypoczynkowe } \\
\text { dla gości }\end{array}$ \\
\hline $\begin{array}{l}\text { Klub Jeździecki } \\
\text { Szumawa, Piaseczno } \\
\text { (BW, WD) }\end{array}$ & + & + & 30 & $\begin{array}{l}\text { Stajnie, padoki, } 2 \text { place } \\
\text { treningowe, kryta hala } \\
\text { ujeżdżalni, kryty lonżownik, } \\
\text { budynki gospodarcze, dom } \\
\text { klubowy, parking dla gości, } \\
\text { tereny wypoczynku dla dzieci } \\
\text { i dorosłych, kryty basen } \\
\text { pływacki }\end{array}$ \\
\hline
\end{tabular}




\begin{tabular}{|l|c|c|c|l|}
\hline \multicolumn{1}{|c|}{$\begin{array}{c}\text { Nazwa klubu } \\
\text { i lokalizacja }\end{array}$} & $\begin{array}{c}\text { Jazda } \\
\text { rekreacyjna }\end{array}$ & $\begin{array}{c}\text { Jazda } \\
\text { sportowa }\end{array}$ & $\begin{array}{c}\text { Liczba } \\
\text { koni }\end{array}$ & $\begin{array}{c}\text { Program funkcjonalny } \\
\text { i infrastruktura klubu }\end{array}$ \\
\hline $\begin{array}{l}\text { Ludowy Klub } \\
\text { Sportowy, Sekcja } \\
\text { Jeździecka Wolta, } \\
\text { Źłłwin k. Brwinowa } \\
\text { (BW, WD) }\end{array}$ & + & + & 38 & $\begin{array}{l}\text { Stajnie, padoki, 2 czworoboki } \\
\text { konkursowe, 2 place } \\
\text { treningowe, hala ujeżdżalni } \\
\text { krytej, budynki gospodarcze, } \\
\text { budynek klubowy, parking } \\
\text { dla gości, rozległe tereny } \\
\text { sportowo-wypoczynkowe dla } \\
\text { dzieci i dorosłych }\end{array}$ \\
\hline $\begin{array}{l}\text { SKJ Trawers, } \\
\text { Wolica (Paszków) } \\
\text { k. Nadarzyna } \\
\text { (BW, WD) }\end{array}$ & + & + & 75 & $\begin{array}{l}\text { Stajnie, padoki, 2 ujeżdżalnie, } \\
\text { kros, dom klubowy, parking } \\
\text { dla gości, miejsce wypoczynku } \\
\text { dla dzieci i dorosłych }\end{array}$ \\
\hline
\end{tabular}

Źródło: Badania terenowe w wybranych klubach jeździeckich aglomeracji warszawskiej (ds.-114 oraz ds.-144 AWF Warszawa); oznaczenia: BP - etap badań pilotażowy, BW - etap badań właściwych, WD - weryfikacja danych

Tabela 2. Dostępność ośrodków jazdy konnej - odległość od centrum Warszawy (PKiN) i czas dojazdu

\begin{tabular}{|l|c|c|c|}
\hline \multicolumn{1}{|c|}{ Nazwa klubu i lokalizacja } & $\begin{array}{c}\text { Odległość } \\
\text { od centrum } \\
\text { Warszawy, } \\
\text { PKiN [km] }\end{array}$ & $\begin{array}{c}\text { Czas } \\
\text { dojazdu } \\
\text { amochodem } \\
\text { osobowym } \\
{[\text { minuty] }}\end{array}$ & $\begin{array}{c}\text { Czas } \\
\text { dojazdu } \\
\text { ransportem } \\
\text { ublicznym } \\
\text { [minuty] }\end{array}$ \\
\hline Klub Cavallo Łazienki Królewskie (BP, WD) & 3,8 & 8 & 24 \\
\hline Klub Pociecha Park Skaryszewski (BP, WD) & 5,1 & 13 & 19 \\
\hline $\begin{array}{l}\text { Klub Jeździecki TWKS Tory Służewieckie } \\
\text { (BP, WD) }\end{array}$ & 8,6 & 16 & 37 \\
\hline $\begin{array}{l}\text { Klub Jeździecki Aldragho, Józefosław, } \\
\text { Piaseczno (BW, WD) }\end{array}$ & 17,8 & 33 & 73 \\
\hline $\begin{array}{l}\text { Klub jeździecki Aromer, Józefin k. Zakrętu } \\
\text { (BW, WD) }\end{array}$ & 24 & 30 & 56 \\
\hline $\begin{array}{l}\text { Filmowa Stajnia Treningowa Bałaguła } \\
\text { w Dabrowie Leśnej k. Łomianek (BW, WD) }\end{array}$ & 18,3 & 23 & 28 \\
\hline $\begin{array}{l}\text { Ośrodek Jeździecki PGR Bródno Sp. z o.o. } \\
\text { Warszawa (BW, WD) }\end{array}$ & 9,2 & 18 & 64 \\
\hline $\begin{array}{l}\text { Klub jeździecki Dworek w Okuniewie k. } \\
\text { Warszawy (BW, WD) }\end{array}$ & 24,1 & 31 & \\
\hline
\end{tabular}




\begin{tabular}{|c|c|c|c|}
\hline Nazwa klubu i lokalizacja & $\begin{array}{l}\text { Odległość } \\
\text { od centrum } \\
\text { Warszawy, } \\
\text { PKiN [km] }\end{array}$ & $\begin{array}{c}\text { Czas } \\
\text { dojazdu } \\
\text { amochodem } \\
\text { osobowym } \\
\text { [minuty] }\end{array}$ & $\begin{array}{c}\text { Czas } \\
\text { dojazdu } \\
\text { ransportem } \\
\text { ublicznym } \\
\text { [minuty] }\end{array}$ \\
\hline Ośrodek Jeździecki Eko-Farm (BW, WD) & 38,9 & 32 & 43 \\
\hline Ognisko TKKF Hubert Warszawa (BW, WD) & 7,7 & 17 & 33 \\
\hline $\begin{array}{l}\text { Klub Jeździecki Legia Kozielska, Warszawa } \\
\text { (BW, WD) }\end{array}$ & 6,3 & 15 & 34 \\
\hline $\begin{array}{l}\text { Kuclandia - LKJ. Klub jeździecki, Książenice } \\
\text { k. Warszawy (BW, WD) }\end{array}$ & 35 & 40 & 85 \\
\hline $\begin{array}{l}\text { Uczniowski Klub Sportowy Szkoła Jazdy } \\
\text { Konnej PATATAJ Kanie k. Pruszkowa (BW, } \\
\text { WD) }\end{array}$ & 26,4 & 34 & 110 \\
\hline $\begin{array}{l}\text { Ośrodek jeździecki Pepeland Dziekanów } \\
\text { Nowy } \\
\text { k. Łomianek (BW, WD) }\end{array}$ & 23,5 & 25 & 60 \\
\hline $\begin{array}{l}\text { TKKF Ognisko Podkowa, Podkowa Leśna } \\
\text { k. Warszawy (BW, WD) }\end{array}$ & 28,6 & 38 & 94 \\
\hline Stajnia Agmaja, Warszawa (BW, WD) & 7,6 & 25 & 31 \\
\hline $\begin{array}{l}\text { Stajnia Chojnów, Baniocha k. Warszawy (BW, } \\
\text { WD) }\end{array}$ & 25,2 & 43 & 120 \\
\hline $\begin{array}{l}\text { Klub Jeździecki Szumawa, Piaseczno (BW, } \\
\text { WD) }\end{array}$ & 26,8 & 35 & 64 \\
\hline $\begin{array}{l}\text { Ludowy Klub Sportowy, Sekcja Jeździecka } \\
\text { Wolta, Żółwin k. Brwinowa (BW, WD) }\end{array}$ & 29 & 38 & 93 \\
\hline $\begin{array}{l}\text { SKJ Trawers, Wolica (Paszków) k. Nadarzyna } \\
\text { (BW, WD) }\end{array}$ & 21,8 & 27 & 76 \\
\hline
\end{tabular}

Źródło: Badania terenowe w wybranych klubach jeździeckich aglomeracji warszawskiej (ds.-114 oraz ds.-144 AWF Warszawa); oznaczenia: BP - etap badań pilotażowy, BW - etap badań właściwych, WD - weryfikacja danych 


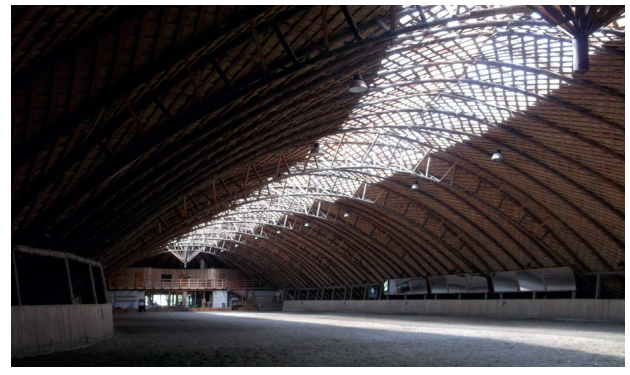

Ryc. 3. Klub jeździecki Chojnów Baniocha pod Warszawą

Niebanalna konstrukcja krytej ujeżdżalni jest przykładem oryginalnej i kreatywnej myśli inżynierskiej

Fot. A. Pawlikowska-Piechotka, 2016

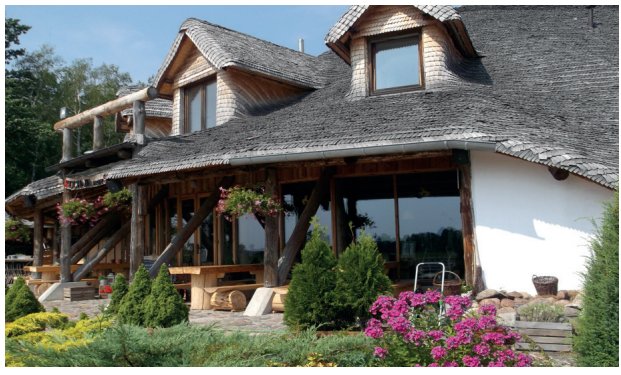

Ryc. 4. Część klubowa ośrodka jeździeckiego Chojnów Baniocha pod Warszawą Znakomita i znana koneserom restauracja jest jednym $z$ atutów tego klubu

Fot. A. Pawlikowska-Piechotka, 2016

\section{Program oferty klubowej, zatrudniona kadra}

Oferta badanych ośrodków jeździeckich obejmowała najczęściej naukę jazdy konnej rekreacyjnej i sportowej, prowadzonych na różnych poziomach zaawansowania, przejażdżki na koniu dla dzieci i dorosłych, przejażdżki bryczką lub zimą saniami, w połowie ośrodków organizowano kursy na odznakę jeździecką PZJ. W ofercie dla członków klubów były ponadto: kolonie dla dzieci, obozy i rajdy konne. Stajnia Chojnów miała niezwykłą ofertę wczasów w siodle zagranica, np. wyjazdy do Argentyny. We wszystkich klubach, położonych poza Warszawa, oferowane były przejażdżki bryczką i saniami, przejażdżki na kucach dla dzieci, imprezy integracyjne, festyny, ogniska i pikniki hippiczne. Część klubów organizuje zawody sportowe - klubowe, regionalne i ogólnopolskie. Wśród badanych klubów sześć prowadziła stałe zajęcia hipoterapii: Klub Pociecha Warszawa, KJ PGR Bródno, KJ Eko-Farm Milanówek, TKKF Hubert Warszawa, KJ Patataj Kanie, TKKF Podkowa Leśna. Należy dodać, że dosyć wyjątkową ofertę ma KJ Bałaguła w Dąbrowie Leśnej k. Łomianek, mianowicie trening i wypożyczanie koni do pracy w filmie (ryc. 5, 6).

W badanych ośrodkach kadrę stanowili najczęściej instruktorzy rekreacji konnej, instruktorzy sportu jeździeckiego oraz trenerzy jeździectwa. Im bardziej urozmaicona oferta ośrodka, tym większe wymagania muszą być stawiane zatrudnionej kadrze. Badane kluby jeździeckie małe i średniej wielkości, w zależności od potrzeb i liczby godzin zajęć, zatrudniały na ogół od dwóch (KJ Aldragho) do kilku (KJ Aromer, KJ Dworek w Okuniewie, Stajnia Agmaja) certyfikowanych instruktorów i trenerów. Duże ośrodki jeździeckie, mające wiele godzin urozmaiconych zajęć na rożnym poziomie zaawansowania, zatrudniały na ogół powyżej 10 osób. W kilku ośrodkach kadra trenerska i instruktorska była przygotowana do prowadzenia zajęć z cudzoziemcami, np. KJ Bałaguła w Dąbrowie Leśnej k. Łomianek - w językach angielskim, niemieckim i rosyjskim, co ośrodki w swojej ofercie chętnie podkreślały. Cena jazd klubowych była w takim wypadku o 10\%-20\% wyższa. Ponadto kluby zatrudnia- 
ły, w zależności od potrzeb, od kilku do kilkunastu osób potrzebnych do prac biurowych, obsługi lokalu gastronomicznego, sklepu z akcesoriami jeździeckimi, pracowników potrzebnych do konserwacji obiektów oraz, w zależności od liczby zwierząt, potrzebny zespół stajennych oraz pracowników fizycznych (tabela 3).

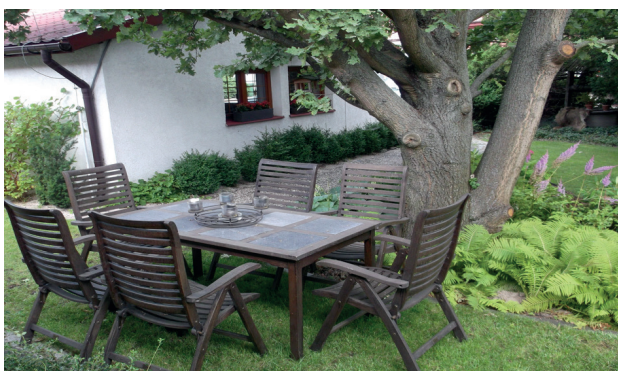

Ryc. 5. Ogródek przy klubie Patataj w Kaniach pod Warszawą

Estetyczna i przyjazna część klubowa, miejsce odpoczynku i spotkań towarzyskich dla klubowiczów i ich rodzin

Fot. A. Pawlikowska-Piechotka, 2016

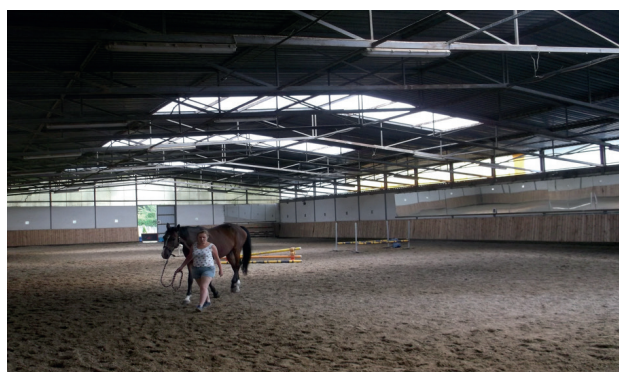

Ryc. 6. Ośrodek jazdy konnej Aromer w Józefinie pod Warszawą Wnętrze krytej ujeżdżalni. Jest to jeden z niewielu ośrodków silnie nastawionych na trening sportowy i organizację zawodów

Fot. A. Pawlikowska-Piechotka, 2016

Tabela 3. Oferta ośrodków jeździeckich oraz zatrudniona kadra trenerska i instruktorska

\begin{tabular}{|l|l|l|}
\hline \multicolumn{1}{|c|}{$\begin{array}{c}\text { Nazwa klubu } \\
\text { i lokalizacja }\end{array}$} & \multicolumn{1}{|c|}{${\text { Kadra ośrodka }{ }^{4}}^{\prime}$} & \multicolumn{1}{c|}{ Oferta klubu } \\
\hline $\begin{array}{l}\text { Klub Cavallo Łazienki } \\
\text { Królewskie (BP, WD) }\end{array}$ & $\begin{array}{l}\text { instruktor rekreacji konnej } \\
(1)\end{array}$ & $\begin{array}{l}\text { Nauka jazdy konnej (tylko } \\
\text { rekreacyjna), przejażdżki dla } \\
\text { dzieci na kucach, pensjonat dla } \\
\text { koni }\end{array}$ \\
\hline $\begin{array}{l}\text { Klub Pociecha Park } \\
\text { Skaryszewski (BP, WD) }\end{array}$ & $\begin{array}{l}\text { instruktor rekreacji konnej } \\
(2)\end{array}$ & $\begin{array}{l}\text { Nauka jazdy konnej (tylko } \\
\text { rekreacyjna), hipoterapia, }\end{array}$ \\
$\begin{array}{l}\text { Klub Jeździecki TWKS } \\
\text { Tory Służewieckie } \\
\text { (BP, WD) }\end{array}$ & $\begin{array}{l}\text { trener jeździectwa (5), } \\
\text { instruktor sportu (4), } \\
\text { instruktor rekreacji konnej } \\
(3)\end{array}$ & $\begin{array}{l}\text { Nauka jazdy konnej, pensjonat dla } \\
\text { koni }\end{array}$ \\
\hline
\end{tabular}

\footnotetext{
${ }^{4} \mathrm{~W}$ zestawieniu nie uwzględniono kadry zatrudnionej przy zajęciach hipoterapii, ze względu na brak takich danych.
} 


\begin{tabular}{|c|c|c|}
\hline $\begin{array}{l}\text { Nazwa klubu } \\
\text { i lokalizacja }\end{array}$ & Kadra ośrodka ${ }^{4}$ & Oferta klubu \\
\hline $\begin{array}{l}\text { Klub Jeździecki } \\
\text { Aldragho, Józefosław, } \\
\text { Piaseczno (BW, WD) }\end{array}$ & $\begin{array}{l}\text { trener jeździectwa (2), } \\
\text { instruktor sportu (1), } \\
\text { instruktor rekreacji konnej } \\
\text { (1) }\end{array}$ & $\begin{array}{l}\text { Nauka jazdy konnej, kursy na } \\
\text { odznake jeździecka, przejażdżki } \\
\text { dla dzieci na kucach, przejażdżki } \\
\text { bryczką i saniami, organizacja } \\
\text { zawodów, obozów i rajdów } \\
\text { konnych, }\end{array}$ \\
\hline $\begin{array}{l}\text { Klub jeździecki } \\
\text { Aromer, Józefin k. } \\
\text { Zakrętu } \\
\text { (BW, WD) }\end{array}$ & $\begin{array}{l}\text { trener jeździectwa (2), } \\
\text { instruktor sportu (2), } \\
\text { instruktor rekreacji (2) }\end{array}$ & $\begin{array}{l}\text { Nauka jazdy konnej, kursy na } \\
\text { odznakę, kursy instruktorskie, } \\
\text { organizacja zawodów, obozów } \\
\text { i rajdów konnych, imprezy } \\
\text { rekreacyjne (pikniki hippiczne), } \\
\text { ambulatorium i opieka } \\
\text { weterynaryjna dla koni, pensjonat } \\
\text { dla koni, }\end{array}$ \\
\hline $\begin{array}{l}\text { Filmowa Stajnia } \\
\text { Treningowa Bałaguła } \\
\text { w Dąbrowie Leśnej } \\
\text { k. Łomianek (BW, WD) }\end{array}$ & $\begin{array}{l}\text { Instruktor rekreacji konnej } \\
(1), \text { instruktor sportu (1) }\end{array}$ & $\begin{array}{l}\text { Nauka jazdy konnej, jazdy } \\
\text { sportowej (skoki, woltyżerka, } \\
\text { powożenie), jazdy rekreacyjne } \\
\text { w terenie, trening i wypożyczanie } \\
\text { koni do pracy w filmie, hotel } \\
\text { dla koni, organizacja zawodów } \\
\text { klubowych, pensjonat dla koni }\end{array}$ \\
\hline $\begin{array}{l}\text { Ośrodek Jeździecki } \\
\text { PGR Bródno Sp. z o.o. } \\
\text { Warszawa (BW, WD) }\end{array}$ & $\begin{array}{l}\text { instruktor rekreacji konnej } \\
\text { (3) }\end{array}$ & $\begin{array}{l}\text { Nauka jazdy konnej, kursy na } \\
\text { odznakę jeździecka, hipoterapia, } \\
\text { organizacja zawodów } \\
\text { jeździeckich, pensjonat dla koni }\end{array}$ \\
\hline $\begin{array}{l}\text { Klub jeździecki } \\
\text { Dworek w Okuniewie } \\
\text { k. Warszawy (BW, } \\
\text { WD) }\end{array}$ & $\begin{array}{l}\text { trener jeździectwa (1), } \\
\text { instruktor sportu (2), } \\
\text { instruktor rekreacji konnej } \\
\text { (3) }\end{array}$ & $\begin{array}{l}\text { Nauka jazdy konnej, woltyżerki } \\
\text { i powożenia, przejażdżki bryczką } \\
\text { i saniami, przejażdżki dla dzieci } \\
\text { na kucach, półkolonie dla } \\
\text { dzieci latem i zima, organizacja } \\
\text { zawodów jeździeckich, pikniki } \\
\text { hippiczne, możliwość zamówienia } \\
\text { prywatnych imprez, pensjonat dla } \\
\text { koni }\end{array}$ \\
\hline
\end{tabular}




\begin{tabular}{|c|c|c|}
\hline $\begin{array}{l}\text { Nazwa klubu } \\
\text { i lokalizacja }\end{array}$ & Kadra ośrodka ${ }^{4}$ & Oferta klubu \\
\hline $\begin{array}{l}\text { Ośrodek Jeździecki } \\
\text { Eko-Farm (BW, WD) }\end{array}$ & $\begin{array}{l}\text { instruktor sportu (1), } \\
\text { instruktor rekreacji konnej } \\
\text { (3) }\end{array}$ & $\begin{array}{l}\text { Nauka jazdy konnej, kursy na } \\
\text { odznakę, hipoterapia, przejażdżki } \\
\text { dla dzieci na kucach, przejażdżki } \\
\text { bryczką i saniami, jazdy w terenie, } \\
\text { półkolonie dla dzieci, organizacja } \\
\text { zawodów regionalnych } \\
\text { i towarzyskich, pensjonat dla koni }\end{array}$ \\
\hline $\begin{array}{l}\text { Ognisko TKKF Hubert } \\
\text { Warszawa (BW, WD) }\end{array}$ & $\begin{array}{l}\text { instruktor sportu (3), } \\
\text { instruktor rekreacji konnej } \\
\text { (10) }\end{array}$ & $\begin{array}{l}\text { Nauka jazdy konnej, kursy na } \\
\text { odznakę jeździecka, hipoterapia, } \\
\text { przejażdżki dzieci na kucach, } \\
\text { przejażdżki bryczka, organizacja } \\
\text { obozów i rajdów konnych, } \\
\text { półkolonie dla dzieci ('Lato } \\
\text { w mieście'), organizacja zawodów } \\
\text { regionalnych i towarzyskich, } \\
\text { pensjonat dla koni }\end{array}$ \\
\hline $\begin{array}{l}\text { Klub Jeździecki Legia } \\
\text { Kozielska, Warszawa } \\
\text { (BW, WD) }\end{array}$ & $\begin{array}{l}\text { trener jeździectwa (1), } \\
\text { instruktor sportu (2), } \\
\text { instruktor rekreacji konnej } \\
\text { (1) }\end{array}$ & $\begin{array}{l}\text { Nauka jazdy konnej, kursy } \\
\text { i egzaminy na odznakę } \\
\text { jeździecka, organizacja zawodów } \\
\text { regionalnych i ogólnopolskich, } \\
\text { organizacja pikników } \\
\text { hippicznych, jazdy w terenie, } \\
\text { pensjonat dla koni }\end{array}$ \\
\hline $\begin{array}{l}\text { Kuclandia - LKJ. Klub } \\
\text { jeździecki, Książenice } \\
\text { k. Warszawy (BW, } \\
\text { WD) }\end{array}$ & $\begin{array}{l}\text { instruktor rekreacji (1), } \\
\text { trener jeździectwa (1) }\end{array}$ & $\begin{array}{l}\text { Nauka jazdy konnej (w tym } \\
\text { woltyżerka, skoki), kursy na } \\
\text { odznakę jeździecka, przejażdżki } \\
\text { dla dzieci na kucach, przejażdżki } \\
\text { bryczką i saniami, organizacja } \\
\text { zawodów w skokach i ujeżdżaniu, } \\
\text { imprezy klubowe, pensjonat dla } \\
\text { koni }\end{array}$ \\
\hline
\end{tabular}




\begin{tabular}{|c|c|c|}
\hline $\begin{array}{l}\text { Nazwa klubu } \\
\text { i lokalizacja }\end{array}$ & Kadra ośrodka ${ }^{4}$ & Oferta klubu \\
\hline $\begin{array}{l}\text { Uczniowski Klub } \\
\text { Sportowy Szkoła Jazdy } \\
\text { Konnej PATATAJ Kanie } \\
\text { k. Pruszkowa (BW, } \\
\text { WD) }\end{array}$ & $\begin{array}{l}\text { trener jeździectwa (2), } \\
\text { instruktor sportu (4), } \\
\text { instruktor rekreacji konnej } \\
\text { (8) }\end{array}$ & $\begin{array}{l}\text { Nauka jazdy konnej, szkolenia } \\
\text { kadry instruktorskiej, hipoterapia, } \\
\text { przejażdżki dla dzieci na kucach, } \\
\text { przejażdżki bryczką i saniami, } \\
\text { organizacja półkolonii, kolonii, } \\
\text { obozów i jadów konnych, } \\
\text { organizacja zawodów, turniejów } \\
\text { rycerskich i pokazów woltyżerki, } \\
\text { pikniki hippiczne, imprezy } \\
\text { prywatne, jazdy terenowe, } \\
\text { pensjonat dla koni }\end{array}$ \\
\hline $\begin{array}{l}\text { Ośrodek jeździecki } \\
\text { Pepeland Dziekanów } \\
\text { Nowy k. Łomianek } \\
\text { (BW, WD) }\end{array}$ & $\begin{array}{l}\text { trener jeździectwa (1), } \\
\text { instruktor sportu (1), } \\
\text { instruktor rekreacji konnej } \\
\text { (3) }\end{array}$ & $\begin{array}{l}\text { Nauka jazdy konnej, przejażdżki } \\
\text { dla dzieci na kucach, przejażdżki } \\
\text { bryczką i saniami, dla dzieci - na } \\
\text { kucach, organizowanie pikników } \\
\text { hippicznych i imprez prywatnych }\end{array}$ \\
\hline $\begin{array}{l}\text { Towarzystwo } \\
\text { Krzewienia Kultury } \\
\text { Fizycznej Ognisko } \\
\text { Podkowa, Podkowa } \\
\text { Leśna k. Warszawy } \\
\text { (BW, WD) }\end{array}$ & $\begin{array}{l}\text { instruktor rekreacji konnej } \\
(10) \text {, trener jeździectwa (1) }\end{array}$ & $\begin{array}{l}\text { Nauka jazdy konnej, kursy na } \\
\text { odznake jeździecka, hipoterapia, } \\
\text { przejażdżki bryczką i saniami, } \\
\text { przejażdżki dzieci na kucach, } \\
\text { organizacja obozów i rajdów } \\
\text { konnych, organizacja zawodów } \\
\text { Liga Mazowsza oraz regionalnych, } \\
\text { zawodów akademickich } \\
\text { w skokach i ujeżdżaniu, } \\
\text { organizacja pikników } \\
\text { hippicznych, "Hubertusów”, } \\
\text { Święta Drugiego Pułku Ułanów } \\
\text { Grochowskich, jazdy w terenie, } \\
\text { pensjonat dla koni }\end{array}$ \\
\hline $\begin{array}{l}\text { Stajnia Agmaja, } \\
\text { Warszawa (BW, WD) }\end{array}$ & $\begin{array}{l}\text { trener jeździectwa (1), } \\
\text { instruktor sportu (5), } \\
\text { instruktor rekreacji konnej } \\
\text { (5) }\end{array}$ & $\begin{array}{l}\text { Nauka jazdy konnej, hipoterapia } \\
\text { dla dzieci, przejażdżki na kucach, } \\
\text { organizacja obozów i kolonii, } \\
\text { organizacja zawodów jeździeckich } \\
\text { klubowych, organizacja pikników } \\
\text { hippicznych, możliwość imprez } \\
\text { prywatnych, pensjonat dla koni }\end{array}$ \\
\hline
\end{tabular}




\begin{tabular}{|c|c|c|}
\hline $\begin{array}{l}\text { Nazwa klubu } \\
\text { i lokalizacja }\end{array}$ & Kadra ośrodka ${ }^{4}$ & Oferta klubu \\
\hline $\begin{array}{l}\text { Stajnia Chojnów, } \\
\text { Baniocha k. Warszawy } \\
\text { (BW, WD) }\end{array}$ & $\begin{array}{l}\text { instruktor sportu (1), } \\
\text { trener jeździectwa (1), } \\
\text { instruktor rekreacji konnej } \\
\text { (3) }\end{array}$ & $\begin{array}{l}\text { Nauka jazdy konnej, przejażdżki } \\
\text { bryczką i saniami, organizacja } \\
\text { wczasów i obozów w siodle (także } \\
\text { zagranica), organizacja zawodów } \\
\text { klubowych, pensjonat dla koni }\end{array}$ \\
\hline $\begin{array}{l}\text { Klub Jeździecki } \\
\text { Szumawa, Piaseczno } \\
\text { (BW, WD) }\end{array}$ & $\begin{array}{l}\text { instruktor sportu (1), } \\
\text { instruktor rekreacji konnej } \\
\text { (3) }\end{array}$ & $\begin{array}{l}\text { Nauka jazdy, przejażdżki na } \\
\text { kucach dla dzieci, organizacja } \\
\text { zawodów klubowych, możliwość } \\
\text { imprez prywatnych, oferta } \\
\text { hotelarska dla klubowiczów, } \\
\text { pensjonat dla koni }\end{array}$ \\
\hline $\begin{array}{l}\text { Ludowy Klub } \\
\text { Sportowy, Sekcja } \\
\text { Jeździecka Wolta, } \\
\text { Żółwin k. Brwinowa } \\
\text { (BW, WD) }\end{array}$ & $\begin{array}{l}\text { instruktor sportu (1), } \\
\text { instruktor rekreacji konnej } \\
\text { (3) }\end{array}$ & $\begin{array}{l}\text { Nauka jazdy, przejażdżki } \\
\text { bryczką i saniami, dla dzieci } \\
\text { przejażdżki na kucach, organizacja } \\
\text { obozów i rajdów konnych, } \\
\text { organizacja zawodów sportowych } \\
\text { w ujeżdżaniu, organizacja } \\
\text { pikników hipicznych i festynów } \\
\text { gminnych (Dożynki Brwinowa), } \\
\text { możliwość imprez prywatnych, } \\
\text { jazdy w terenie, pensjonat dla koni }\end{array}$ \\
\hline $\begin{array}{l}\text { SKJ Trawers, Wolica } \\
\text { (Paszków) k. } \\
\text { Nadarzyna (BW, WD) }\end{array}$ & $\begin{array}{l}\text { instruktor rekreacji konnej } \\
\text { (4), trener jeździectwa (3) }\end{array}$ & $\begin{array}{l}\text { Nauka jazdy konnej (specjalizacja: } \\
\text { dzieci od } 2 \text { roku życia), kursy } \\
\text { i egzaminy na odznakę jeździecka, } \\
\text { przejażdżki na kucach dla dzieci, } \\
\text { organizacja pikników hipicznych, } \\
\text { jazdy w terenie, pensjonat dla koni }\end{array}$ \\
\hline
\end{tabular}

Źródło: Badania terenowe w wybranych klubach jeździeckich aglomeracji warszawskiej (ds.-114 oraz ds.-144 AWF Warszawa) oznaczenia: BP - etap badań pilotażowy, BW - etap badań właściwych, WD - weryfikacja danych

\section{Plany rozwoju klubów}

Poważnym utrudnieniem w czasie prowadzonych badań było uzyskanie w kilku klubach odpowiedzi na pytania dotyczące planów rozwoju ośrodka w przyszłości. W trakcie wywiadu z właścicielami lub zarządzającymi unikano odpowiedzi na to pytanie, bądź twierdzono, także w ośrodkach zdecydowanie wymagających ulepszeń, że żadnych planów inwestycji w najbliższej przyszłości nie przewidziano, ponieważ - zdaniem właścicieli - stan 
klubu jest zadowalający ${ }^{5}$. Z kolei właściciele klubu KJ Dworek w Okuniewie widzieliby wiele możliwości doinwestowania ośrodka, ale nie mieli ani możliwości terenowych, ani finansowych. Podobnie dzierżawca KJ Trawers w Wolicy, mając potrzebę takich inwestycji jak dom klubowy i pensjonat, kryta ujeżdżalnia, karuzela dla koni, nie przewidywał możliwości ich realizacji, ponieważ były odrzucane przez właściciela ośrodka, zezwalającego wyłącznie na bieżące drobne remonty istniejących już budynków i urządzeń terenowych. Właściciele KJ Szumawa w Piasecznie planowali poszerzenie już istniejącej oferty hotelarskiej, a zarządzający KJ Stajnia Agmaja w Warszawie planowali dom klubowy o bogatym programie (sanitariaty, szatnie, pomieszczenia techniczne, lokal gastronomiczny i świetlicę). Zarządzający KJ TKKF Podkowa Leśna planowali krytą ujeżdżalnię, karuzelę dla koni, remonty istniejących obiektów. Właściciel KJ Pepeland w Łomiankach planował wzmocnienie oferty treningów sportowych i dalszy rozwój oferty jazd rekreacyjnych. Zarządzający KJ Patataj w Kaniach planował powiększenie stajni i budowę stałej krytej ujeżdżalni. W KJ Kuclandia planowana jest zewnętrzna myjka oraz założenie dla dzieci szkółki jazd na małych kucykach. W KJ Legii Kozielskiej planowane były remonty budynków, przebudowa stajni kontenerowej (blaszanej) na murowana, przebudowa karuzeli na obiekt kryty, wymiana nawierzchni hipodromu. W TKKF Hubert Warszawa planowano rozbudowanie infrastruktury - ze względu na problemy zatwierdzania inwestycji i ograniczeń finansowych - raczej nie w najbliższej przyszłości. W KJ Eko-Farm Milanówek planowano m.in. remonty budynków, rozbudowanie pensjonatu dla koni, wzmocnienie oferty treningów sportowych. W KJ PGR Bródno zaplanowano dalszy rozwój kursów nauki jazdy, wymianę koni, organizacje większej liczby imprez. Właściciele KJ Aromer planowali budowę segmentu hotelowego dla gości ośrodka (25 pokoi z łazienkami). Zarządzający KJ Aldragho w Józefosławiu planowali budowę solarium dla koni, karuzeli, krytej myjki, krytego lonżownika, remonty istniejących obiektów i podnoszenie ich standardu.

\section{Informacja na temat klubów i promocja oferty}

Należy podkreślić, że właściciele i zarządzający klubami przywiązywali dużą wagę do promocji klubów i rzetelnej informacji o prowadzonej działalności. Tablice informacyjne i banery reklamowe znajdują się w pobliżu klubów, są umieszczane przy ruchliwych i lokalnych drogach, a ponadto informacje o klubach znajduja się w sieci. W czasie pierwszego etapu badań jedynie Klub Cavallo w Warszawie miał swoją stronę internetowa, w czasie drugiego etapu badań tylko dwa kluby nie miały stron w Internecie, a w czasie trzeciego etapu badań wszystkie wybrane do badań kluby jeździeckie miały już swoje strony internetowe, większość ogłaszała się jeszcze dodatkowo na platformach społecznych, typu FB.

\footnotetext{
${ }^{5}$ Należy podejrzewać, że nie są to szczere odpowiedzi. Za dyskrecją właścicieli kryje się najprawdopodbniej chęć ukrycia planów (uważanych za 'tajemnicę handlowa' firmy). Tematem tabu są także pytania dotyczące dochodów jakie mają ośrodki jazdy konnej oraz liczby członków klubów jeździeckich.
} 


\section{Koszty członkostwa i innych usług}

Pomimo wysiłków powtarzanych w czasie trzech kolejnych etapów badań, w kilku klubach stanowczo odmówiono informacji na temat liczby członków klubu, wybieranych najczęściej zajęciach oraz nie udostępniono cennika oferty klubowej. Część zarządzających argumentowała odmowę tym, że ceny usług są indywidualnie negocjowane z klientami. Odmawiając odpowiedzi na pytanie o liczbę członków klubu dowodzili najczęściej, że w tym wypadku obowiązuje ich tajemnica handlowa. Pomimo braku pełnych danych, dla porównania cennika ofert w badanych klubach, zdecydowano się je analizować i interpretować, uważając, że nawet niepełna informacja w znaczący sposób rzuci światło na uwarunkowania uprawiania jeździectwa w aglomeracji warszawskiej. W badanych ośrodkach zróżnicowanie ofert cenowych jazd konnych dochodziło do 50\%. Jazda konna indywidualna z instruktorem (1 godzina, weekend) kosztowała przeciętnie 100 PLN. Najtańszą ofertę miał klub Eko-Farm Milanówek oraz TKKF Podkowa Leśna (70 PLN), najdroższą KJ Legia Kozielska i Stajnia Chojna Baniocha (120 PLN). Należy dodać, że większość badanych ośrodków proponowała klubowiczom wykupywanie karnetów lub naukę jazdy konnej w grupie, a wtedy ceny sa niższe. W klubach obowiązywało zróżnicowanie ceny jazd w zależności od stopnia zaawansowania oraz ukierunkowania nauki. Dobrym przykładem takiego bardzo szczegółowego cennika była oferta KJ Patataj w Kaniach. Najmniej kosztowały tam krótkie (do 30 minut) jazdy rekreacyjne $\mathrm{w}$ grupie (35 PLN), a specjalistyczny indywidualny trening sportowy szczególnie skoki - były zdecydowanie najdroższe (110 PLN). Klubowicze w niektórych ośrodkach jeździeckich mogli dzierżawić konia na wyłączne dla siebie jazdy, co przeciętnie stanowiło około 1500 PLN miesięcznie.

Znaczące zróżnicowanie cen usług występowało też w cenniku pensjonatu dla koni, przekraczając $50 \%$. W badanych ośrodkach cena pensjonatu dla konia wahała się od 900 PLN (Stajnia Agmaja Warszawa, KJ Dworek w Okuniewie) do 1900 PLN (Stajnia Chojnów Baniocha) za jeden miesiąc pobytu. Inaczej zatem niż w przypadku cennika jazd konnych, ceny pensjonatu nie zależały od położenia ośrodka i odległości od centrum Warszawy. Tak znaczące różnice wynikały przede wszystkim z różnicy świadczeń: w cenie najtańszego pensjonatu było wynajęcie boksu dla konia, opieka, karmienie (Stajnia Agmaja Warszawa). W innych ośrodkach w ofercie mieściły się dodatkowe świadczenia, takie jak opieka weterynaryjna, środki do pielęgnacji. Na tle innych ośrodków wyjątkowo bogatą ofertę pensjonatu miała Stajnia Chojnów Baniocha. W cenie pensjonatu oferowano - poza wynajęciem boksu, karmieniem, opieką i treningiem konia - także środki do pielęgnacji konia, opiekę weterynaryjną i kowala. W wielu ośrodkach jazdy konnej, jeżeli właściciel zgodził się wynajmować konia do jazd rekreacyjnych, cena pensjonatu mogła być znacząco zredukowana (na przykład w KJ Patataj o 50\%) (tabela 4). 
Tabela 4. Przykładowe ceny ofert ośrodków jazdy konnej

\begin{tabular}{|c|c|c|}
\hline Nazwa klubu i lokalizacja & $\begin{array}{c}\text { Cena jazdy konnej } \\
\text { indywidualnej } \\
\text { z instruktorem - godzina } \\
\text { jazdy w weekend } 6 \\
\text { [PLN] }\end{array}$ & $\begin{array}{l}\text { Cena hotelu dla } \\
\text { konia - miesiąc } \\
\text { pobytu } \\
\text { z wyżywieniem } \\
\text { [PLN] }\end{array}$ \\
\hline $\begin{array}{l}\text { Klub Cavallo Łazienki Królewskie (BP, } \\
\text { WD) }\end{array}$ & 100 & 1800 \\
\hline $\begin{array}{l}\text { Klub Pociecha Park Skaryszewski (BP, } \\
\text { WD) }\end{array}$ & 100 & brak oferty \\
\hline $\begin{array}{l}\text { Klub Jeździecki TWKS Tory } \\
\text { Służewieckie (BP, WD) }\end{array}$ & 80 & brak oferty \\
\hline $\begin{array}{l}\text { Klub Jeździecki Aldragho, Józefosław, } \\
\text { Piaseczno (BW, WD) }\end{array}$ & do negocjacji & do negocjacji \\
\hline $\begin{array}{l}\text { Klub jeździecki Aromer, Józefin k. } \\
\text { Zakrętu (BW, WD) }\end{array}$ & do negocjacji & 1400 \\
\hline $\begin{array}{l}\text { Filmowa Stajnia Treningowa Bałaguła } \\
\text { w Dabrowie Leśnej k. Łomianek (BW, } \\
\text { WD) }\end{array}$ & do negocjacji & do negocjacji \\
\hline $\begin{array}{l}\text { Ośrodek Jeździecki PGR Bródno Sp. Zoo } \\
\text { Warszawa (BW, WD) }\end{array}$ & 90 & do negocjacji \\
\hline $\begin{array}{l}\text { Klub jeździecki Dworek w Okuniewie } \\
\text { k. Warszawy (BW, WD) }\end{array}$ & 90 & 900 \\
\hline Ośrodek Jeździecki Eko-Farm (BW, WD) & 70 & do negocjacji \\
\hline $\begin{array}{l}\text { Ognisko TKKF Hubert Warszawa (BW, } \\
\text { WD) }\end{array}$ & $\begin{array}{l}80 \text { (ujeżdzeniowa) } \\
100 \text { (skokowa) }\end{array}$ & brak ofert \\
\hline $\begin{array}{l}\text { Klub Jeździecki Legia Kozielska, } \\
\text { Warszawa (BW, WD) }\end{array}$ & 120 & 1500 \\
\hline $\begin{array}{l}\text { Kuclandia - LKJ. Klub jeździecki, } \\
\text { Książenice k. Warszawy (BW, WD) }\end{array}$ & 100 & do negocjacji \\
\hline $\begin{array}{l}\text { Uczniowski Klub Sportowy Szkoła } \\
\text { Jazdy Konnej PATATAJ Kanie k. } \\
\text { Pruszkowa (BW, WD) }\end{array}$ & $75-115$ & 1000 \\
\hline $\begin{array}{l}\text { Ośrodek jeździecki Pepeland Dziekanów } \\
\text { Nowy k. Łomianek (BW, WD) }\end{array}$ & 110 & brak oferty \\
\hline
\end{tabular}

\footnotetext{
${ }^{6} \mathrm{~W}$ przypadku zajęć z instruktorem prowadzonych w językach obcych - cena wzrasta o $10 \%-20 \%$.
} 


\begin{tabular}{|c|c|c|}
\hline Nazwa klubu i lokalizacja & $\begin{array}{c}\text { Cena jazdy konnej } \\
\text { indywidualnej } \\
\text { z instruktorem - godzina } \\
\text { jazdy w weekend }{ }^{6} \\
\text { [PLN] }\end{array}$ & $\begin{array}{l}\text { Cena hotelu dla } \\
\text { konia - miesiąc } \\
\text { pobytu } \\
\text { z wyżywieniem } \\
\text { [PLN] }\end{array}$ \\
\hline $\begin{array}{l}\text { Towarzystwo Krzewienia Kultury } \\
\text { Fizycznej Ognisko Podkowa, Podkowa } \\
\text { Leśna k. Warszawy (BW, WD) }\end{array}$ & 70 & brak ofert \\
\hline Stajnia Agmaja, Warszawa (BW) & 100 & 900 \\
\hline $\begin{array}{l}\text { Stajnia Chojnów, Baniocha k. Warszawy } \\
\text { (BW, WD) }\end{array}$ & 120 & 1900 \\
\hline $\begin{array}{l}\text { Klub Jeździecki Szumawa, Piaseczno } \\
\text { (BW, WD) }\end{array}$ & 110 & 1500 \\
\hline $\begin{array}{l}\text { Ludowy Klub Sportowy, Sekcja } \\
\text { Jeździecka Wolta, Żółwin k. Brwinowa } \\
\text { (BW, WD) }\end{array}$ & do negocjacji & do negocjacji \\
\hline $\begin{array}{l}\text { SKJ Trawers, Wolica (Paszków) k. } \\
\text { Nadarzyna (BW, WD) }\end{array}$ & do negocjacji & brak oferty \\
\hline
\end{tabular}

Źródło: Badania terenowe w wybranych klubach jeździeckich aglomeracji warszawskiej (ds.-114 oraz ds.-144 AWF Warszawa); oznaczenia: BP - etap badań pilotażowy, BW - etap badań właściwych, WD - weryfikacja danych

\section{Czynniki społeczno-kulturowe sprzyjające i bariery rozwoju jeździectwa}

Na podstawie analizy zgromadzonego materiału badań, można było zidentyfikować te czynniki społeczno-kulturowe, które mają szczególne znaczenie dla upowszechniania sportu i rekreacji jeździeckiej, jak i te, które są dla nich barierami. Pozytywny wpływ, pośredni lub bezpośredni, na rozwój ośrodków jazdy konnej mają:

- $\quad$ rozumienie i szanowanie historii i tradycji jeździectwa w Polsce, o czym świadczy duży odsetek odpowiedzi twierdzacych na pytania o kolekcjonowanie wydawnictw związanych z jeździectwem, kolekcjonowanie pamiątek i dzieł sztuki o tej tematyce,

- fascynacja jazdą konna, koniem, jego inteligencją i uroda, miłość do zwierząt i potrzeba ich bliskości, o czym świadczą odpowiedzi twierdzace na pytania o stosunek do zwierzat,

- pochodzenie z rodziny, a szerzej środowiska, w którym jazda konna jest popularna i jest ważnym sposobem spędzania wolnego czasu; wciąż silna identyfikacja z tradycja jeździecką np. w rodzinie i przechowywanie fotografii tę tradycję dokumentujących,

- uleganie modzie i „lansowanym” przez media stylu życia wyższej klasy średniej (jazda konna jest atrybutem wizerunku tej grupy obok gry w polo i gry w golfa); aspiracje do stylu życia typowego dla klas zamożnych i chęć zaimponowania znajomym,

- przywiązywanie znaczenia do miłej, kulturalnej i towarzyskiej atmosfery w klubie, 
udział w imprezach sportowych i towarzyskich tam organizowanych; członkowstwo w klubie zaspokaja potrzeby kontaktów społecznych, daje satysfakcję kontaktu z osobami o podobnych pasjach, zainteresowaniach i stylu życia,

- uprawianie jeździectwa z rodziną bądź przyjaciółmi (członkostwo w klubie wzmacnia istniejące więzi rodzinne i towarzyskie), świadczą o tym pozytywne odpowiedzi na temat sposobu spędzania wolnego czasu, ulubioną formę urlopu wypoczynkowego,

- $\quad$ wykształcenie wyższe i wyższe od przeciętnych dochody - takiego bezpośredniego pytania nie było, ale pośrednio możemy wnioskować o sytuacji materialnej z odpowiedzi udzielonych na zapytanie o dłuższe urlopy, w tym spędzane za granica,

- przywiązywanie wagi do zdrowego trybu życia, przestrzeganie diety i regularne uprawianie innych sportów, uczestnictwo w innych niż jazda konna formach rekreacji, o czym świadcza pozytywne odpowiedzi większości ankietowanych,

- znajomość faktów świadczących o pozytywnym wpływie jazdy konnej na zdrowie i samopoczucie, na jakość życia - w tym walkę ze stresem, poprawę kondycji fizycznej i psychicznej,

- pasja sportowa i chętne startowanie w zawodach, także w innych dyscyplinach niż jeździectwo, o czym świadczą odpowiedzi ankietowanych,

- chęć uczenia się i doskonalenia swojej techniki i stylu jazdy poprzez regularne ćwiczenia, uczestnictwo w kursach i jazdy z instruktorem,

- miłość do zwierząt (uprawiający jeździectwo często hodują własnego konia, psa lub inne zwierzę), czerpanie przyjemności i satysfakcji z możliwości kontaktu z koniem.

Wśród czynników mających negatywny wpływ, pośrednio lub bezpośrednio, na rozwój jeździectwa należy wymienić:

- wysokie koszty finansowe i znacząca czasochłonność tej formy sportu i rekreacji,

- problemy z dostępnością komunikacyjną klubów jeździeckich,

- $\quad$-brak tradycji rodzinnych (środowiska społecznego, w którym badana osoba przebywa) jazdy konnej, jako sposobu spędzania wolnego czasu,

- brak zainteresowania sportem i aktywnym trybem życia,

- lęk przed koniem,

- uzasadnione przeciwwskazania lekarskie, np. alergia na zapach i sierść konia,

- niska ocena własnej sprawności, nieuzasadnione obawy, że stan zdrowia i sprawność fizyczna wykluczają tę formę rekreacji,

- $\quad$ wstyd podejmowania zajęć sportowych i rekreacyjnych z powodu wyglądu lub/i wieku

- orzeczona niepełnosprawność i brak dostępu do ośrodka jeździeckiego z oferta terapii, parajeździectwa lub nauki jazdy konnej dostosowanych do potrzeb tej grupy,

- obawa przed napuszoną atmosfera, snobizmem i elitarnością klubu, lęk przed dezaprobata i odrzuceniem ze strony innych członków klubu. 


\section{Dyskusja - bariery w upowszechnianiu jeździectwa i możliwości ich znoszenia}

Biorąc pod uwagę zidentyfikowane czynniki hamujące rozwój ośrodków jazdy konnej, można zaproponować następujące sposoby znoszenia barier dostępności do oferty klubowej.

\section{Mało urozmaicona oferta ośrodków jazdy konnej}

Chociaż jazda konna jest teoretycznie możliwa przez cały rok, w badanych ośrodkach oferta letnia i frekwencja na zajęciach, przekładająca się na dochody i płynność finansowa, znacząco przeważa nad zimowa, zwłaszcza, że w okresie letnich wakacji łatwiej jest zainteresować klubowiczów koloniami, obozami i rajdami konnymi. Z tego powodu wiele klubów jazdy konnej powinno oferować wiele atrakcji wykraczających poza samą jazdę wierzchem, takie jak przejażdżki bryczka, kuligi, korty tenisowe, place do gier zespołowych, mini golf, dobrze urządzone i utrzymane tereny zabaw dla dzieci, bogatą ofertę atrakcji 'pod dachem', jak kryte baseny itp. Oferta ośrodka powinna także uwzględniać tych członków rodzin, którzy nie jeżdżą konno, ale pragną spędzać wspólne wakacje, dni wolne i świąteczne. Dla nich, oprócz propozycji lekcji jazdy konnej dla początkujących, oprowadzania, powinny być organizowane przejażdżki bryczka, a w wypadku obozu wędrownego - możliwość przejazdu wozem taborowym lub powozem, rowerem. Walcząc o klientów, pozamiejskie ośrodki jazdy konnej, szczególnie te nastawione na wielodniowy pobyt gości, powinny zapewnić również szereg atrakcji poza sama jazdą konna, takie jak m.in.: wyprawy rowerowe, zajęcia fitness, jogging, nordic walking, kapieliska, miejsca wędkowania, boiska do gier zespołowych (siatkówki i piłki nożnej), ping-pong, mini golf, badminton, boule, strzelanie z łuku, możliwość zorganizowania gry w paintball, spływu kajakowego, rejsu żaglówka, zwiedzanie okolicznych zabytków, szkolenie strzeleckie z broni palnej. Oczywiście taką ofertę moga mieć jedynie większe ośrodki z rozbudowanym zapleczem, liczną dobrze wykwalifikowaną kadrą i odpowiednimi rezerwami terenowymi. Na podstawie zebranych opinii klubowiczów okazuje się, że zawsze mile widziane są organizowane dla członków i przyjaciół doroczne imprezy, np. spod znaku świętego Huberta, zawody klubowe otwarte 'dla wszystkich'. Coroczne 'Hubertusy', które odbywają się jesienia, połączone z klubowymi uroczystościami czy regularne zawody, z pewnościa pomoga budować tradycje klubu i wzmacniać więzi towarzyskie klubowiczów. Ponieważ mamy tradycje w sztukach pięknych tematyki jeździeckiej, wydaje się, że wydawanie albumów poświęconych temu tematowi, wystawy rzeźby, malarstwa i grafiki współczesnych twórców zajmujących się tematyką jeździecką w ośrodkach jazdy konnej byłby nie tylko miłym urozmaiceniem oferty, ale mogłyby pełnić istotną rolę promocyjną i edukacyjną. 


\section{Wysokie koszty uczestnictwa w rekreacji i sporcie jeździeckim}

Z badań terenowych i wywiadów, nieformalnych rozmów z członkami klubów oraz obserwacji jawnych, zarówno uczestniczących jak i nieuczestniczących wynika, że niezwykle istotna bariera uprawiania jeździectwa, rekreacyjnego czy sportowego, jest wysoki koszt i czasochłonność tej formy sportu i rekreacji. Trudno jest odpowiedzieć na pytanie, do jakiego poziomu można redukować koszty jazdy konnej i jak wielki jest wciąż margines zysków właścicieli ośrodków, z którego byliby skłonni rezygnować. Obserwując jednak tendencje w ofercie ośrodków i stale rosnącą bogatą i urozmaiconą ofertę ośrodków luksusowych, nastawionych przede wszystkim na klubowiczów bardzo zamożnych, należy podkreślić, że tym samym jest odczuwalny brak ośrodków skromniejszych, o zredukowanej ofercie adresowanej do zdecydowanie mniej zamożnej klienteli. Wydaje się, że szczególnie w takich klubach możliwość odpracowania pracami fizycznymi lub biurowymi na rzecz klubu godzin jazd konnych byłaby niezmiernie pożądana - obecnie tylko TKKF 'Hubert' ma takie propozycje. Na podstawie przeprowadzonych badań jesteśmy zdania, że wciąż brakuje klubów jeździeckich zapewniających lekcje jazdy i prowadzących wypożyczalnie akcesoriów jeździeckich w granicach dostępnych cen dla osób o średnich i niskich dochodach, np. uczniów szkół średnich, studentów, rodzin wielodzietnych. Trudno sobie wyobrazić inną drogę do upowszechniania tej formy sportu i rekreacji niż obniżanie cen. Naturalnie poniżej pewnego poziomu, wyznaczanego przez wartość konia i jego utrzymanie, cen obniżać się nie da. Zważywszy jednak społeczną rolę i potencjalne, wielorakie korzyści tej formy aktywności i mając na uwadze jego upowszechnianie a nie dążenie do elitarności - kolejnym, wartym zastanowienia rozwiązaniem jest dofinansowanie ośrodków jeździeckich, szczególnie działających w uboższych gminach, ze źródeł zewnętrznych. Rozważane powinny być, w znacznie szerszym niż obecnie zakresie, bezpłatne lekcje jazdy konnej dla dzieci i młodzieży, organizowane w ramach zajęć WF, półkolonii, kolonii, obozów letnich, finansowanych dzięki współpracy z urzędami gmin, kuratoriami oświaty. Przy współpracy z urzędem miasta i gminy można wprowadzać system zniżek i ulg dla mieszkańców, płacacych na danym obszarze podatki (na wzór TKKF Podkowa Leśna), a jednocześnie wprowadzać ulgi podatkowe dla ośrodków, jako instytucji świadczących pożyteczną działalność na rzecz społeczności lokalnej. Tylko jeden z badanych ośrodków (KJ Szumawa pod Piasecznem) ubiegał się skutecznie o środki unijne na rozwój klubu. Uzyskał je i budowa krytej pływalni oraz urządzenie terenów wypoczynkowych wokół były z tego źródła sfinansowane. Wydaje się więc, że i to źródło pozyskiwania środków nie jest wciąż dostatecznie wykorzystane.

\section{Czasochłonność uprawiania jeździectwa}

Istotnym czynnikiem, który limituje znacząco dostępność do jazd konnych to zasoby wolnego czasu. Ośrodki jazdy konnej są na ogół zlokalizowane w strefach podmiejskich, na terenach byłych gospodarstw rolnych. Dojazd do nich, szybki i niemęczący, wymaga własne- 
go samochodu, dojazd środkami transportu publicznego oznacza ponad godzinna, uciążliwą podróż z przesiadkami. Ponieważ około godzinę przed jazdą właściwą należy przeznaczyć na przygotowanie siebie i konia do jazdy, na uporządkowanie boksu w stajni - w efekcie jazdy są możliwe najczęściej w weekendy i w czasie urlopu. Z tego też względu zdecydowanie wciąż rację bytu mają ośrodki jeździeckie położone w granicach administracyjnych miast, do których dojazd rowerem lub komunikacją publiczną jest ułatwiony.

\section{Bariery uczestnictwa w sporcie i rekreacji jeździeckiej osób niepełnosprawnych: hipoterapia, parajeździectwo}

Obok funkcji ekonomicznej, wychowawczej, ekologicznej, wypoczynkowej uprawiania jeździectwa niezmiernie ważna jest funkcja zdrowotna. Na przeszkodzie uczestniczenia w hipoterapii stoja przede wszystkim bariery finansowe. Niestety, obecnie ani NFZ, ani powołane fundacje nie są w stanie zapewnić wszystkim potrzebującym zajęć rehabilitacyjnych w wymaganym zakresie. Należy podkreślić, że np. TKKF Hubert w Warszawie proponuje zajęcia hipoterapii w swoim ośrodku jeździeckim przy ulicy Statkowskiego w zamian za odpracowanie przez opiekunów chorych dzieci oferowanych godzin terapii prostymi pracami fizycznymi na rzecz ośrodka. Zainteresowanie jednak taką oferta, jak się wydaje znakomicie wychodzącą naprzeciw potrzebom rodziców i dzieci - okazało się minimalne. Ten sam problem dotyczył ograniczonej liczby osób uprawiających parajeździectwo, pomimo wykwalifikowanej kadry i dobrze przygotowanych do takich zadań koni.

\section{Niedostateczna edukacja i promocja jazdy konnej}

Wciąż istnieje konieczność budowania bardziej przekonującego wizerunku jeździectwa, jako 'sportu dla wszystkich', sportu demokratycznego, pozbawionego elitarności i snobizmu, podkreślania dobroczynnego wpływu jazdy konnej na sprawność fizyczną i kondycję psychiczną osób w każdym wieku. W czasie warsztatów edukacyjnych w klubie lub lekcji szkolnych można wprowadzać temat historii jeździectwa w kontekście historii Polski, zalet jeździectwa w kontekście zdrowia fizycznego i psychicznego. Ponieważ jazda konna uczy szacunku do świata przyrody, empatii wobec zwierząt, pomaga kształtować postawy proekologiczne wydaje się, że jest to kolejny, ważny powód nawiązania przez ośrodki współpracy z kuratoriami oświaty, szkołami w sąsiedztwie. Zajęcia w formie wycieczek do klubu, warsztatów i lekcji jazdy moga być przedłużane na okres wakacji w formie kolonii, półkolonii czy obozów wędrownych dla starszej młodzieży. Warto podkreślić, że większość badanych klubów miała w ofercie takie zajęcia, cieszą się jednak umiarkowaną popularnością. Jest to chyba kolejny argument za koniecznością ściślejszej współpracy ośrodków ze szkołami, kuratoriami oświaty i samorządem terytorialnym. Być może efektywna współpraca rozpoczęłaby się dopiero po podpisaniu odpowiednich porozumień między Polskim Związkiem Jeździeckim a Ministerstwem Edukacji Nauki. 


\section{Wnioski końcowe}

Na podstawie zgromadzonego materiału badań, wydaje się, że powstawanie nowych ośrodków o zróżnicowanej ofercie i wzbogacenie oferty istniejących ośrodków jazdy konnej jest racjonalne: ma sens zarówno ekonomiczny, ekologiczny, kulturowy, jak i społeczny. Należy też podkreślić szczególną wagę popularyzacji jazdy konnej, jako formy wypoczynku dostępnej dla różnych grup społecznych, pomimo wielu pokutujących na ten temat uprzedzeń i dezinformacji.

Przede wszystkim, jak się wydaje, powinny istnieć kluby mniejsze i skromniejsze, z niższą cenowo oferta, dobrze skomunikowane transportem publicznym. Byłoby bowiem błędem zakładać, że współczesne sport i rekreacja jeździecka mają - tak jak przed laty - zabarwienie wyłącznie elitarne, połączone z określoną klasą społeczną. To prawda, że czynne uprawianie sportu i rekreacji jeździeckiej wiążą się z nakładami finansowymi, ale po pierwsze zamożność mieszkańców wielkich miast polskich stale rośnie [GUS 2007, 2015, 2020], z drugiej - dzięki licznie powstającym ośrodkom jazdy konnej - oferta jest zróżnicowana i coraz bardziej dostępna dla różnych grup społecznych [PZJ 2009, 2015, 2020]. Nieporozumieniem, na które warto zwrócić uwagę, jest wyolbrzymianie kosztów jazdy konnej. Na podstawie przeprowadzonych badań wiadomo, że jest wiele niewielkich, skromnych ośrodków, co prawda o słabszym dostępie komunikacyjnym z centrum Warszawy, w których można uczyć się jazdy konnej zimą i jesienią za 50\% ceny ofertowej. Akcesoria jeździeckie, łącznie z butami i toczkiem, można tam wypożyczyć za stosunkowo niewielkie kwoty. A zatem, ta forma sportu i rekreacji ma szansę dalszego rozwoju w przyszłości pod warunkiem utrzymania odpowiednio zróżnicowanej oferty (tabela 5).

Tabela 5. Analiza SWOT oferty ośrodków jazdy konnej na podstawie uogólnionych wniosków z przeprowadzonych badań w aglomeracji warszawskiej

\begin{tabular}{|l|l|}
\hline $\begin{array}{c}\text { Mocne strony ośrodków jazdy } \\
\text { konnej }\end{array}$ & \multicolumn{1}{|c|}{ Możliwości wzmocnienia atutów } \\
\hline $\begin{array}{l}\text { 1. Rozbudowana oferta nauki } \\
\text { i jazd konnych rekreacyjnych } \\
\text { i sportowych }\end{array}$ & $\begin{array}{l}\text { 1. Dbanie o stałą modyfikację oferty i monitoring } \\
\text { efektów } \\
\text { 2. Organizacja zawodów }\end{array}$ \\
sportowych, egzaminów na \\
odznaki jeździeckie & konkursów i zawodów przy współpracy z PZJ, PKOIL, \\
3. Kursy podnoszące & dbanie o promocję i nagłaśnianie imprez, o ich \\
kwalifikacje & odpowiednio atrakcyjną oprawę \\
4. Dobra kadra instruktorska & 3. i 4. Stały rozwój oferty szkoleniowej, udoskonalanie \\
i trenerska & programów, współpraca z podobnymi ośrodkami \\
& za granicą dla wymiany doświadczeń (m.in. \\
& wykorzystanie programów UE) \\
\hline
\end{tabular}




\begin{tabular}{|c|c|}
\hline $\begin{array}{l}\text { Słabe strony ośrodków jazdy } \\
\text { konnej }\end{array}$ & Możliwości niwelowania zjawisk negatywnych \\
\hline $\begin{array}{l}\text { 1. Czasochłonny dojazd } \\
\text { 2. Wysokie koszty uczestnictwa } \\
\text { w jeździe konnej } \\
\text { 3. Brak atrakcyjnej ofert dla } \\
\text { wszystkich członków rodziny } \\
\text { 4. Brak możliwości } \\
\text { atrakcyjnych jazd w terenie } \\
\text { 5. Brak informacji o ośrodku, } \\
\text { złe oznakowanie dojazdu } \\
\text { 6. Mało zróżnicowane pod } \\
\text { względem społecznym } \\
\text { środowisko członków klubów } \\
\text { 7. Zaniedbywanie jazdy } \\
\text { sportowej na rzecz rekreacyjnej } \\
\text { i turystycznej } \\
\text { 8. Niska estetyka ośrodków, } \\
\text { brak harmonijnej, tworzącej } \\
\text { funkcjonalnie i estetycznie } \\
\text { spójną całość zabudowy } \\
\text { 9. Problemy z finansowaniem } \\
\text { działalności, brak środków na } \\
\text { remonty i rozszerzanie oferty }\end{array}$ & $\begin{array}{l}\text { 1. Lokalizacja w okolicy dobrze skomunikowanej } \\
\text { z centrum miasta } \\
\text { 2. Rozbudowanie oferty, zróżnicowanej pod względem } \\
\text { kosztów, możliwość odpracowania (wolontariat } \\
\text { uczniowski, studencki) prostymi pracami fizycznymi } \\
\text { w ośrodku kosztów nauki i jazdy konnej } \\
\text { 3. Rozbudowanie infrastruktury podmiejskich } \\
\text { ośrodków: baseny kryte i otwarte, korty tenisowe } \\
\text { i boiska do gier zespołowych, mini-golf, domy } \\
\text { klubowe, tereny rekreacyjno-wypoczynkowe } \\
\text { urządzone, baby zoo i tereny zabaw dla dzieci } \\
\text { 4. Lokalizacja podmiejskich ośrodków na terenach } \\
\text { umożliwiajacych jazdy terenowe (tereny rolno-leśne) } \\
\text { 5. Dobrze prowadzona strona internetowa, wyraźne } \\
\text { oznakowanie dojazdu (wzdłuż dróg, przy przystankach } \\
\text { komunikacji publicznej) } \\
\text { 6. Warsztaty dla uczniów szkół wszystkich stopni na } \\
\text { temat koni i jeździectwa, współpraca z kuratorium } \\
\text { oświaty i samorządem terytorialnym, system zniżek } \\
\text { i ulg dla początkujących jeźdźców, powoływanie } \\
\text { fundacji } \\
\text { 7. Szukanie sponsorów sportu jeździeckiego, } \\
\text { budowanie wysokiej klasy stajni koni sportowych, } \\
\text { długi i cierpliwy (wieloletni) trening sportowy } \\
\text { - zawodnika i konia; lekcje WF w ośrodkach } \\
\text { organizowane przy współpracy samorządu } \\
\text { terytorialnego i kuratorium oświaty } \\
\text { 8. Większa dbałość o estetykę zabudowy, } \\
\text { przeprowadzanie remontów, rozbudowa infrastruktury } \\
\text { harmonijna, uwzględniająca istniejące budynki, } \\
\text { unikanie przypadkowych dobudówek, szop i wiat, } \\
\text { usuwanie popsutych mebli, elementów małej } \\
\text { architektury, maszyn i urządzeń } \\
\text { 9. Zainteresowanie możliwością uczestniczenia } \\
\text { w programach UE (np. przeznaczonym na rzecz } \\
\text { Rozwoju Regionalnego) }\end{array}$ \\
\hline
\end{tabular}


Wielorakie możliwości, jakie daje ta forma sportu i rekreacji, buduja jej sportowy potencjał w wymiarze społecznym - są to przede wszystkim braki ostrych ograniczeń w stosunku do możliwości jeźdźca - płci, wieku, umiejętności, kondycji fizycznej. Podobnie jak sporty wodne, sporty zimowe, wędrówki turystyczne - jazda konna daje szanse zachowania i polepszenia dobrej kondycji fizycznej i psychicznej przedstawicieli różnych grup społecznych: kobiet i mężczyzn, dzieci i młodzieży, dorosłych i osób starszych, osób bardziej i mniej sprawnych fizycznie, jeźdźców doświadczonych i początkujących. W efekcie, tak jak inne formy aktywności ruchowej, uprawianie zarówno sportowe, jak i rekreacyjne jeździectwa zapewnia wyższą jakość życia: większą sprawność, samodzielność, dobrą kondycję psychofizyczna, dobrostan fizyczny, psychiczny i społeczny.

Naturalnie, z uwagi na rozliczne bariery, jazda konna prawdopodobnie nigdy nie będzie mogła konkurować z popularnością innych form aktywnej rekreacji w mieście: spacerami, nordic walking, joggingiem, pływaniem, zajęciami ogrodniczymi, jazdą na rowerze, na rolkach lub hulajnodze, a zima - biegami i spacerami narciarskimi. Niemniej, zapewnienie zainteresowanym sportem jeździeckim Polakom codziennej możliwości uprawiania jazdy konnej w pobliżu ich miejsca zamieszkania, ma z ogromne znaczenie dla racjonalnego wykorzystania czasu wolnego, promocji zdrowego trybu życia. Bowiem bez względu na to, czy będzie to sportowa pasja, czy jedna z form rodzinnej rekreacji - jazda konna powinna być uważana, tak jak inne formy wypoczynku czynnego - za integralny element programu promocji zachowań prozdrowotnych mieszkańców wielkich miast.

W przeszłości turystyka konna i jazdy rekreacyjne były związane przede wszystkim ze stadninami, natomiast obecnie rozpowszechnia się dzięki ośrodkom jazdy konnej zlokalizowanym na obrzeżach wielkich miast, powstającym w popularnych ośrodkach turystycznych. Obserwowane tendencje, polegające na odchodzeniu coraz większej liczby turystów od wypoczynku biernego na rzecz wypoczynku aktywnego, dobrze rokuje rozwojowi rekreacyjnych jazd konnych na terenach wiejskich. Rosnące wymagania członków klubów, dotyczące jakości usług, wymuszają stałe podnoszenie standardu. Właściciele ośrodków jazdy konnej moga korzystać z różnych źródeł finansowania (m.in. środków z Unii Europejskiej na rzecz Rozwoju Regionalnego), w celu realizacji potrzebnych inwestycji, takich jak baseny, korty tenisowe, wypożyczalnie rowerów [Walter 2012]. Przykładem dobrego wykorzystania takich możliwości jest ośrodek jazdy konnej KJ Szumawa pod Piasecznem.

Motywacją podjęcia tego tematu badań było przede wszystkim przekonanie, że aktywny tryb życia ma ogromne znaczenia nie tylko dla nas samych, ale i dla budowania ściślejszych więzi społecznych - rodzinnych, przyjacielskich. Ponieważ wspólne rekreacyjne i sportowe jazdy konne takie relacje pomagają wzmacniać - stąd nadzieja, że konkluzje z badań, o charakterze uogólnionym, okażą się przydatne do kształtowania atrakcyjnej oferty ośrodków jeździeckich i przyczynia się do dalszego popularyzowania jeździectwa w naszym społeczeństwie. Korzyści upowszechniania tej formy sportu i rekreacji są oczywiste, jest to aktywność fizyczna dostępna 'dla wszystkich', bez względu na wiek, płeć, umiejętności i stopień zaawansowania, stopień sprawności fizycznej, forma sportu i rekreacji dająca bliski kontakt 
ze światem przyrody, a ponadto jeździectwo jest ze względów historycznych, społecznych i kulturowych bardzo ważną tradycją dla Polaków.

Należy także podkreślić, że obecne ograniczenia wyjazdów wakacyjnych, spowodowane pandemią COVID-19, wymuszają poszukiwania atrakcyjnych i bezpiecznych pod względem zdrowotno-sanitarnym warunków aktywnego wypoczynku w pobliżu miejsca zamieszkania [Herman, Drozda 2021]. Ośrodki jazdy konnej w Warszawie, położone na terenach niskozurbanizowanych (Dolina Wisły) i podmiejskich, sa dobrym rozwiązaniem tego problemu. Indywidualny charakter tej formy sportu i rekreacji, pozwalający zachować bezpieczny dystans, jazdy konne w terenie otwartym, gdzie możliwość zakażenia jest minimalna - sa zarówno atrakcyjne, jak i bezpieczne.

\section{Literatura}

Adelman M., Knijnik J. D., 2013, Gender and equestrian sport: riding around the world, Dordrecht Publisher, Springer New York.

Bruch M., 2012, Horse-based Tourism in Iceland - An analysis of the travel motivation of equestrian tourists, Diplomica Verlag, Hamburg.

Chmiel K., 2009, Koń w turystyce i rekreacji, Państwowa Szkoła Wyższa im. Papieża Jana Pawła II, Biała Podlaska.

Cohen L., Manion L., Morrison K., 2008, Research Methods in Education, Routledge, New York.

DiGiacomo M., 2012, Equine Assisted Psychotherapy activity manual: 22 new basic activities created for EAP, EAGALA Publishing, Santaquin, USA.

Domżał A., Należyty M., Solecka I., 2014, Informator Hipoterapii dla lekarzy, specjalistów i rodziców, Zarzad Główny, Polskie Towarzystwo Hipoterapii, Warszawa.

Finn M., Elliott-White M., Walton M., 2000, Tourism and Leisure Research Methods. Data Collection, Analysis and Interpretation, Pearson - Longman, Harlow.

Geld-Pieprzyca I., 2005, Jazda konna elementem kultury w wychowaniu Polaka [w:] Z. Dziubiński (red.), Sport jako kulturowa rzeczywistość, Salezjańska Organizacja Sportowa Rzeczypospolitej Polskiej, Warszawa, s. 535-549.

Goodson L., Phillimore J., 2004, Qualitative Research In Tourism, Routledge, New York.

Grobelny J., 1995, Uwarunkowania rozwoju rekreacji konnej w świetle literatury przedmiotu, Kwartalnik Naukowy AWF Poznań, 3-4, Akademia Wychowania Fizycznego Eugeniusza Piaseckiego w Poznaniu, s. 111-131.

Halemba P., Harmaciński R., 2009, Sport i turystyka osób niepetnosprawnych, Wyższa Szkoła Umiejętności, Kielce. 
Heipertz-Hengst Ch., 1997, Jazda konna osób niepetnosprawnych, Państwowe Wydawnictwo Rolnicze i Leśne, Warszawa.

Herman K., Drozda Ł., 2021, Green Infrastructure in the Time of Social Distancing: Urban Policy and the Tactical Pandemic Urbanism, Sustainability, 13, 4, 1631, DOI: 10.3390/su13041632 (Sustainable Special Issue: Landscapes in the Time of Social Distancing: Pandemic and Design of the Urban Environment, February 2021).

King B.M., 2009, Statystyka dla psychologów i pedagogów, Wydawnictwo Naukowe PWN, Warszawa.

Luxmoore K., 2008, Introduction to equestrian sports, Collingwood Vic Publishing, Landlinks London.

McGreevy P., 2011, Equitation Science, John Wiley \& Sons, Hoboken.

Massini A., 2010, Equine-assisted psychotherapy in clinical practice, Journal of Psychosocial Nursing and Mental Health Services, 48, 10, s. 30-34.

Mogiła-Lisowska J., 2010, Rekreacyjna aktywność ruchowa dorostych Polaków - uwarunkowania, styl uczestnictwa, Akademia Wychowania Fizycznego Józefa Piłsudskiego, Warszawa.

Pawlikowska-Piechotka A., Łukasik N., 2014, Sport i rekreacja w zabytkowych parkach Warszawy, Turystyka i Rekreacja, t. II, Akademia Wychowania Fizycznego Józefa Piłsudskiego, Warszawa, s. 157-165.

SJON, 2014, Parajeździectwo - Informator, Stowarzyszenie Jeździeckie Osób Niepełnosprawnych, Warszawa.

Pilch T., 2001, Zasady badań pedagogicznych: strategie ilościowe i jakościowe, Wydawnictwo Żak, Warszawa.

Siwiński W., 1989, Metody badań pedagogicznych w dziedzinie kultury fizycznej i turystyki, Akademia Wychowania Fizycznego Eugeniusza Piaseckiego w Poznaniu, Poznań.

Straus I., 1996, Hipoterapia: neurofizjologiczna gimnastyka lecznicza na koniu, FnRRRKDN, Kraków.

Straus I., 2013, Hipoterapia. Fizjoterapia na koniu i przy koniu, Fundacja Hipoterapia, Warszawa.

Strumińska A., 2003, Psychopedagogiczne aspekty hipoterapii dzieci i młodzieży niepetnosprawnych intelektualnie, Państwowe Wydawnictwo Rolne i Leśne, Warszawa.

Torkildsen G., 2005, Leisure and Recreation Management, Routledge, London.

Vael A. I., 2011, Leisure and Tourism Policy and Planning, CABI Publishing, London.

Walter Ł., 2012, Finansowanie klubów sportowych, Konie i Rumaki, 10, s. 57-59.

Williams S., 2003, Tourism and Recreation, Prentice Hall, London-New York. 
Wolframm I., 2014, The science of equestrian sports: theory, practice and performance of the equestrian rider, Routledge, Milton Park, Oxon.

Yan J.H., McCullagh P., 2004, Cultural Influence on Youth's Motivation of Participation in Physical Activity, Journal of Sport Behaviour, 27, 4, s. 378-390.

(ZGPTH) Zarząd Główny Polskiego Towarzystwa Hipoterapeutycznego, 2009, Kanony Polskiej Hipoterapii, ZGPTH, Kraków.

\section{Wybrane strony internetowe}

www.stat.gov.pl [dostęp: 2007, 2014, 2015, 2016, 2020]

www.pzj.pl [dostęp: 2009, 2015, 2016, 2020]

www.nocowanie.pl [dostęp: 2020]

www.idara.pl [dostęp: 2020]

www.gromada.pl [dostęp: 2020]

www.oferteo.pl [dostęp: 2020]

\section{Equestrian clubs - an elite offer or available to everyone?}

\section{ABSTRACT}

The subject of the article is to consider the determinants of the development of horse riding in the Warsaw agglomeration. It discusses the determinants of development, potentials and key obstacles, as well as the possibilities of lifting constraints and activities for the promotion of equestrian sport and recreation. This is one of the thematic threads of research carried out in selected equestrian centres in the Warsaw agglomeration as part of two following statutory research projects, supported by a statutory grant from the Ministry of Science and Higher Education ds-114 and ds-144.

On the basis of the collected material, PhD Natalia Łukasik prepared and defended her doctoral dissertation at the Józef Piłsudski University of Physical Education in Warsaw, entitled Social and cultural conditions for the development of horse riding in Warsaw and neighbouring communes (supervisor: Prof, DSc, $\mathrm{PhD}$, Eng Arch. Anna Pawlikowska-Piechotka). The article presents an outline of the research assumptions, the results obtained on the basis of the analysis of the research material and advanced synthetic final conclusions.

Key words: horse riding centres, equestrianism, Warsaw agglomeration 


\title{
116 KLUBY JEŹDZIECKIE - OFERTA ELITARNA CZY DOSTĘPNA DLA WSZYSTKICH?
}

Anna Pawlikowska-Piechotka, Natalia Łukasik

\begin{abstract}
Anna Pawlikowska-Piechotka, prof. dr hab. inż. arch. - architekt i urbanista, w latach 2004-2014 profesor wizytujący na University College Birmingham (Wielka Brytania), Charles University of Prague (Czechy), University of Lahti (Finlandia), University of Saragossa (Hiszpania), University of Evora (Portugalia), University of Viseau (Portugalia), Holar University (Islandia). W swoich badaniach koncentruje się na wykorzystaniu dziedzictwa kulturowego dla zrównoważonego rozwoju turystyki i odpowiedzialnego planowania przestrzeni turystyki, sportu i rekreacji. Uczestniczyła w kilku międzynarodowych projektach badawczych (Niemcy, Szwecja, Holandia, Wielka Brytania, Polska, Turcja); jest autorem ponad dwustu publikacji naukowych, w tym kilku monografii, tekstów opublikowanych w języku angielskim, niemieckim, polskim i serbskim; współautor kilkudziesięciu planów architektonicznych i urbanistycznych (zrealizowanych w Polsce, Niemczech, Nigerii i Libii) oraz wzorów użytkowych obiektów rekreacyjnych dla osób niepełnosprawnych - formalnie zarejestrowanych w Urzędzie Patentowym RP.

Kontakt: Akademia Wychowania Fizycznego Józefa Piłsudskiego w Warszawie; ORCID: 0000000304290327 ;

e-mail:anna.piechotka@gmail.com

Anna Pawlikowska-Piechotka, Prof, PhD Eng, DSc, Arch - architect and urban planner, between 2004-2014 a visiting professor at University College Birmingham (United Kingdom), Charles University of Prague (Czech Republic), University of Lahti (Finland), University of Saragossa (Spain), University of Evora (Portugal), University of Viseu (Portugal), Holar University (Iceland). Focuses in her research on the usage of cultural heritage for sustainable tourism and responsible planning for tourism, sport and recreation. Participated in several international research projects (Germany, Sweden, Holland, UK, Poland, Turkey). Author of over two hundred scientific publications, including several monographs, papers published in English, German, Polish and Serbian. Co-author of several architectural and urban plans of recreation and tourist space (commissioned in Poland, Germany, Nigeria and Libya) and utility models of recreation facilities for disabled - formally registered in the Polish Patent Office.

Contact: the Józef Piłsudski University of Physical Education in Warsaw; ORCID: 000000030429 0327;

e-mail:anna.piechotka@gmail.com
\end{abstract}

Natalia Łukasik jest doktorem nauk o kulturze fizycznej i sporcie. Jest absolwentką studiów magisterskich i doktoranckich Akademii Wychowania Fizycznego Józefa Piłsudskiego w Warszawie, lingwistyki stosowanej na Uniwersytecie Warszawskim oraz Podyplomowych Studiów na Wydziale Geografii i Studiów Regionalnych UW w Warszawie. W czasie stypendiów naukowych studiowała na uczelniach wyższych za granica (Węgry, Niemcy, Meksyk, Finlandia). Jest licencjonowanym pilotem wycieczek i przewodnikiem turystycznym, ma uprawnienia instruktorskie w zakresie jazdy konnej i żeglarstwa. W okresie zatrudnienia na Wydziale Wychowania Fizycznego AWF w Warszawie brała udział w kilku projektach naukowych na temat zrównoważonego rozwoju turystyki oraz sportu i rekreacji na terenach zurbanizowanych. Jest autorkq̨ i współautorkq kilkunastu publikacji naukowych.

Kontakt: Katedra Turystyki i Rekreacji, Wydział Wychowania Fizycznego, Akademia Wychowania Fizycznego Józefa Piłsudskiego w Warszawie; ORCID: $000000020100720 X$

Natalia Łukasik - PhD in physical culture and sports; graduate of the Józef Piłsudski University of Physical Education in Warsaw, the Institute of Applied Linguistics at the University of Warsaw and the Faculty of Geography and Regional Studies at the University of Warsaw. During research scholarships, she studied at universities abroad (Hungary, Germany, Mexico, Finland). Licensed tour leader and tourist guide; has instructor qualifications in the field of horse riding and sailing. During her employment at the Józef Piłsudski University of Physical Education in Warsaw, she participated in several research projects on the sustainable development of tourism, sports and recreation in urban areas. Author and co-author of several scientific publications.

Contact: Faculty of Physical Education, the Józef Piłsudski University of Physical Education in Warsaw; ORCID: $000000020100720 X$ 